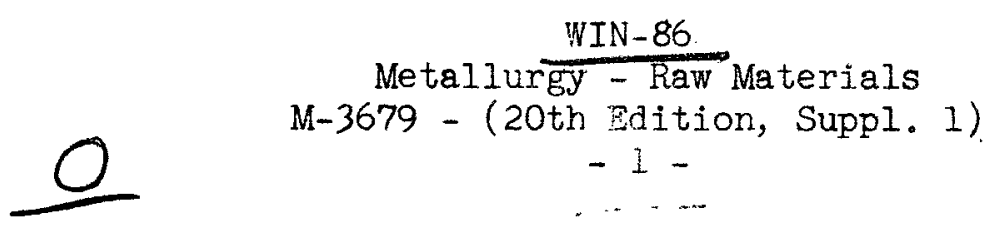

TOPICAL REPORT WIN-86

\title{
QXIDANTS IN CARBONATE LEACHING OF URANIFEROUS ORES
}

By

P. J. Magno and M. A. DeSesa

August 23, 1957
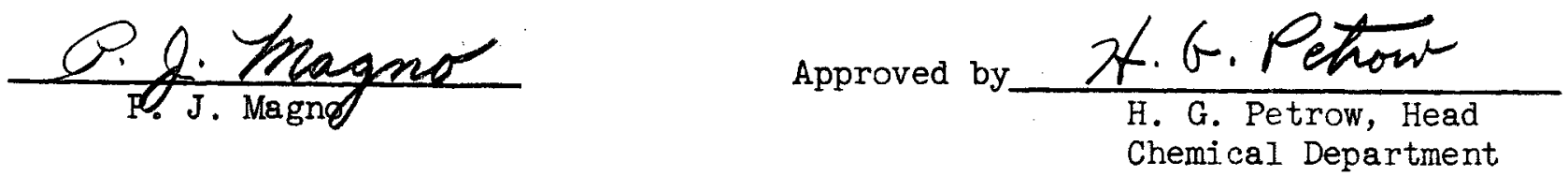

$\frac{\text { m.a. Ae Seea }}{\text { M.A. DeSesa }}$

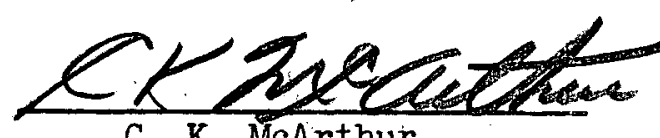
C. K. McArthur, Technical Director

U. S. Atomic Energy Commission Contract No. AT(49-6)-924

National Lead Company, Inc. Raw Materials Development Laboratory Winchester, Massachusetts 


\section{DISCLAIMER}

This report was prepared as an account of work sponsored by an agency of the United States Government. Neither the United States Government nor any agency Thereof, nor any of their employees, makes any warranty, express or implied, or assumes any legal liability or responsibility for the accuracy, completeness, or usefulness of any information, apparatus, product, or process disclosed, or represents that its use would not infringe privately owned rights. Reference herein to any specific commercial product, process, or service by trade name, trademark, manufacturer, or otherwise does not necessarily constitute or imply its endorsement, recommendation, or favoring by the United States Government or any agency thereof. The views and opinions of authors expressed herein do not necessarily state or reflect those of the United States Government or any agency thereof. 


\section{DISCLAIMER}

Portions of this document may be illegible in electronic image products. Images are produced from the best available original document. 
WIN-86

Metallurgy-Raw Materials

M-3679 - (20th Edition, Supp1. 1)

REPORT DISTRIBUTION

External Distribution

Allied Chemical and Dye Corporation

Argonne National Laboratory

Atomic Energy Commission, Washington

Battelle Memorial Institute

Chicago Operations office

Chicago Patent Group

Columbia University (Hassialis)

Division of International Affairs (Bishop)

Division of Raw Materials

Dow Chemical Company, Pittsburg

The Fluor Corporation

General Electric Company, Richland

Grand Junction Operations office

Hanford Operations Office

Iowa State College

Los Alamos Scientific Laboratory

Mallinckrodt Chemical Works

Massachusetts Institute of Technology (B. E. Proctor)

National Lead Company of Ohio

National Lead Company, Inc. (Monticello)

New Brunswick Laboratory

New York Operations office

Patent Branch, Washington

Technical Information Service, Oak Ridge

Union Carbide Nuclear Company (K-25 Plant)

Union Carbide Nuclear Company (ORNL)

U. S. Bureau of Mines, Salt Lake City

University of California Radiation Laboratory, Berkeley

University of Nevada, Mackay School of Mines

Number of

\author{
Copies
}

1

2

2

1

1

1

2

1

12

1

1

2

15

1

1

1

3

1

R. G. Beverly 
WIN-86

-2 -

\section{ABSTRACT}

In order to obtain data on the comparative effectiveness of oxidants for uranium in alkaline carbonate solutions, a variety of reagents were used under identical conditions for the dissolution of nim dioxide in $0.5 \mathrm{M}$ sodium carbonate and $0.5 \mathrm{M}$ sodjum-bicarbonate.

Those oxidants which appeared most promising were evaluated further in leaching studies on E. L. Cord and La Sal ore samples. As a result of these tests, the cupric ammonia complex ion was determined to be the most economical oxidant for the carbonate leaching of uraniferous ores. Further evaluation of the copper-ammonia reagent on other ores, which were known to require an oxidant during carbonate leaching, indicated that this reagent is effective on all ores tested. 


\section{TABLE OF CONTENTS}

Page

INTRODUCTION

SUMMARY

TESTS ON URANIUM DIOXIDE

Experimental Procedure

8

Air Oxidation

8

Evaluation of Oxidants

9

Combination of Oxidants

REGENERATION OF FERRICYANIDE BY HYPOCHLORITE

TESTS ON ORE SAMPLES

Preliminary Evaluation of Oxidants

Detailed Study of Copper-Ammonia Reagent

Copper Concentration

Ammonia Concentration

24

Temperature

Sulfate Buildup

Copper-Bearing Ore as Source of Copper

24

26

Leaching in a Covered Vessel

26

Ion Exchange

27

Leaching Tests on Various Ores

29

30

LITERATURE CITED

32

FIGURES 


\section{INTRODUCTION}

The two reagents commonly used for leaching uranium from its ores are sulfuric acid and a mixture of sodium carbonate and sodium bicarbonate. If the ore contains a high concentration of acid-consuming gangue material such as limestone, alkaline leaching is the only practical process. However, sulfuric acid digestion has been much more widely adopted, in general, because uranium extraction by alkaline reagents has not been as high as with acid. Yet carbonate leaching does offer the advantages of relatively selective uranium extraction, negligible corrosion problems, and recycle of the leaching reagents. Therefore it seems that if the extraction efficiency of carbonate leaching can be improved, carbonate leaching may be more widely adopted.

One of the most critical factors in carbonate leaching is oxidation of the uraniurn to the hexavalent state which is extremely soluble in carbonate solutions in comparison to tetravalent uranium which is quite insoluble. Oxygen is a satisfactory oxidant, and effective oxidation can be obtained by air agitation of the ore pulp at atmospheric pressure and elevated temperature. When there is a need for more rapid oxidation than is possible by bubbling air through the pulp, ores are also treated with potassium permanganate ej.ther in autoclaves or atmospheric leach tanks. This investigation into oxidants for the efficient dissolution of uranium from ores amenable to carbonate leaching at atmospheric pressure was made as part of a fundamental study of the carbonate leach process. Most of the oxidants tested have been previously examined at the Raw Materials Development Laboratory $(1-3)$, the Chemical Research Laboratory in England (4-7), the Canadian Department of Mines and Technical Surveys (8), and A. D. Iittle Inc. $(9,10)$. Several substitutes for permanganate have been suggested in the past but none have been adopted, possibly because of the fact that different leaching conditions and various uranium oxides and uraniferous ores were used in these tests so that it was difficult to compare data. reported from the various installations. 
WIN-86

$-5-$

In this report are presented first the results of a series of screening tests in which various oxidants were evaluated singly and in combinations under identical conditions to determine their effectiveness in promoting the dissolution of uranium dloxide in carbonate-bicarbonate solution. Also reported are the results of alkaline leaching tests with the more promising of the oxidants on ore samples, which were known to require oxidation. Finally, a detailed study of the copper-ammonia reagent, which was judged to be most efficient and economical, is presented. 


\section{SUMMARY}

A variety of chemicals were tested for their efficiency as oxidants to promote the dissolution of uranium dioxide in $0.5 \mathrm{M}$ sodium carbonate and $0.5 \mathrm{M}$ sodium bicarbonate solution. The following chemicals gave no improvement over air oxidation: sodium bismuthate, $\mathrm{NaBiO}_{3}$, potassium nitrate, $\mathrm{KNO}_{3}$, sodium nitrite, $\mathrm{NaNO}_{2}$, potassium chlorate, $\mathrm{KClO}_{3}$, sodium perchlorate, $\mathrm{NaClO}_{4}$, potassium dichromate, $\mathrm{K}_{2} \mathrm{Cr}_{2} \mathrm{O}_{7}$, nickel sequioxide, $\mathrm{Ni}_{2} \mathrm{O}_{3}$, and cupric sulfate, $\mathrm{CuSO}_{4} \cdot 5 \mathrm{H}_{2} \mathrm{O}$. Lead dioxide, $\mathrm{PbO}_{2}$, and lead tetraoxide, $\mathrm{Pb}_{3} \mathrm{O}_{4}$, caused an improvement in the rate of oxidation as compared to air oxidation but were definitely less efficient than potassium permanganate. Potassium peroxydisulfate, $\mathrm{K}_{2} \mathrm{~S}_{2} \mathrm{O}_{8}$, hydrogen peroxide, $\mathrm{H}_{2} \mathrm{O}_{2}$, sodium hypochlorite, $\mathrm{NaOCl}$, and copper sulfate plus ammonia were about as efficient as permanganate. Mercurous chloride, $\mathrm{Hg}_{2} \mathrm{Cl}_{2}$, mercuric chloride, $\mathrm{HgCl}_{2}$, potassium ferricyanide, $\mathrm{K}_{3} \mathrm{Fe}(\mathrm{CN}) 6$ and silver sulfate, $\mathrm{Ag}_{2} \mathrm{SO}_{4}$, were definitely superior oxidants as compared to potassium permanganate for the dissolution of uranium dioxide in carbonate-bicarbonate solution.

The very effective oxidants mercuric chloride, potassium ferricyanide, and silver sulfate were tested in combination with sodium hypochlorite, potassium peroxydisulfate, and potassium permanganate. A small amount of mercuric chloride was effective in increasing the oxidation efficiency of sodium hypochlorite and potassium peroxydisulfate. Silver sulfate caused a substantial increase in the efficiency of sodium hypochlorite.

On the basis of oxidation capacity and reagent cost, potassium ferricyanide, sodium hypochlorite, sodium hypochlorite with mercuric chloride added, and copper sulfate with ammonium hydroxide were tested on E. L. Cord Ore, Sample 365-I, and their efficiency compared with permanganate and air oxidation. Because of high oxidizing capacity and low cost, the copper-ammonia reagent was judged to be the most attractive substitute for permanganate. 
Further leaching tests were made on LaSal ore, a composite of Samples 189-3-5-6-7-8, to determine optimum concentrations of copper and ammonia. A conservative estimate of optimum reagent concentrations was made at $4 \mathrm{lb} /$ ton copper sulfate and $6 \mathrm{lb} /$ ton ammonia for a total cost of about $\$ 0.82$ as compared to $12 \mathrm{lb} /$ ton of potassium permanganate required for this ore at a cost of about $\$ 3.60$.

The versatility of the copper-ammonia reagent was demonstrated when efficient 24-hour extractions of 94 to $98 \%$ were obtained with $2 \mathrm{lb} /$ ton copper sulfate and $8 \mathrm{lb} /$ ton ammonia at a cost of $\$ 0.66$ on samples of Utex, Richardson Claim, Los Ochos, Ralston Creek, Ambrosia Lake, Moonlight Claim, North Alice, and Globe Mining Ores.

The effect of leaching temperature was evaluated and the optimum temperature was determined to be 85 to $90^{\circ} \mathrm{C}$. Higher temperatures caused a decrease in uranium extraction probably because ammonia was boiled out of the solution and the copper precipitated.

Sulfate buildup in the recycled leach solution should cause no problems because leaching tests conducted with as much as 45 grams per liter of sulfate as sodium sulfate indicated no deleterious effect on the rate of dissolution of uranium.

Pregnant leach liquors prepared with the copper-ammonia oxidant should be amenable to alkaline ion exchange since it was found that negligible amounts of copper are adsorbed by XE-123 anion exchange resin from carbonate-bicarbonate solutions.

Finally, it was shown that an ore containing copper may be substituted as the source of cupric ions when $97 \%$ of the uranium was solubilized from a $1: 1$ blend of White Canyon and LaSal ore upon leaching for 24 hours with $8 \mathrm{lb} /$ ton of ammonia alone in a solution containing 50 grams of sodium carbonate and 20 grams of sodium bicarbonate per liter. 


\section{TESTS ON URANIUM DIOXIDE}

\section{EXPERTMENTAI PROCEDURE}

In order to obtain data on the comparative effectiveness of oxidants for the dissolution of uranium in carbonatebicarbonate solutions, a variety of oxidants were tested under identical conditions. These studies were made at atmospheric pressure in one-liter reaction flasks fitted with a stainless steel stirrer, a reflux condenser, a thermometer, and a glass tube with a sintered glass frit through which samples were withdrawn from solution. In each test, one gram of minus 48-mesh (50\% minus 325-mesh) uranium dioxide, $\mathrm{UO}_{2}$, was added with the oxidant to one liter of $0.5 \mathrm{M}$ sodium carbonate and $0.5 \mathrm{M}$ sodium bicarbonate ( $53 \mathrm{~g} \mathrm{Na} 2 \mathrm{CO}_{3} / 1$ and $42 \mathrm{~g} \mathrm{NaHCO} / 1 /$ ) at $70^{\circ} \mathrm{C}$. The solutions were continuously agitated, and samples were withdrawn at various intervals and analyzed for dissolved uranium. From these data a rate curve of percent uranium dioxide dissolved for various time intervals was drawn.

\section{AIR OXIDATION}

In order to have a reference curve with which to compare the effectiveness of the various chemical oxidants, the rate of dissolution of uranium dioxide under the above standard leaching conditions was determined without the addition of a chemical oxidant. In this case, the dissolution takes place as a result of the air oxidation of the uranium dioxide. Also, to determine the effect of introducing air directly into the leach solution, a test was made in which air at a rate of $50 \mathrm{cc}$ per minute was introduced into the leach solution by means of a medium porosity frit. Results of these tests are presented in Table I on the following page. 


\section{Table I}

\section{Rate of Dissolution of Uranium Dioxide Using Air as the Only Oxidant}

Time in Hours

1

2

3

4

5

6

7
\& $\mathrm{UO}_{2}$ Dissolved Air Flow in cc/min<smiles>CC=[OH+]</smiles>
50

4.2

7.1

11.1

14.2

16.9

20.0

22.7
$4 \cdot 4$

7.9

12.0

15.4

18.6

21.6

24.1

1) A considerable amount of air is drawn down into the leach solution as a result of the agitation.

These results show that the rate of dissolution of uranium dioxide is slow without the addition of a chemical oxidant. The positive introduction of air into the leach solution did result in a small increase in the rate of dissolution. In all of the following tests using uranium dioxide, no positive introduction of air into the leach solution was made.

\section{EVALUATION OF OXIDANTS}

The following chemicals were found to be ineffective oxidants for the dissolution of uranium dioxide: $\mathrm{NaBiO}_{3}, \mathrm{KNO}_{3}, \mathrm{NaNO}_{2}$, $\mathrm{NaClO}_{4}, \mathrm{KClO}_{3}, \mathrm{~K}_{2} \mathrm{Cr}_{2} \mathrm{O}_{7}, \mathrm{Ni}_{2} \mathrm{O}_{3}$, and $\mathrm{CuSO}_{4}$. The extractions obtained with those chemicals which were found to be effective oxidants are summarized in Table II on the following page. 


\section{Table II}

Effect of Oxidants on the Rate of Dissolution of Uranium Dioxide

\begin{tabular}{|c|c|c|}
\hline Oxidant & $\begin{array}{c}\text { Concentration } \\
\text { Grams/Liter }\end{array}$ & $\begin{array}{l}\% \mathrm{UO}_{2} \mathrm{D} \\
\text { in Six } \\
\end{array}$ \\
\hline None & - & 20 \\
\hline $\mathrm{KMnO}_{4}$ & 0.39 & 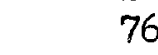 \\
\hline $\mathrm{H}_{2} \mathrm{O}_{2}{ }^{4}$ & 0.13 & \\
\hline $\mathrm{K}_{2} \mathrm{~S}_{2} \mathrm{O}_{8}$ & 1.00 & \\
\hline $\mathrm{NaOCl}$ & 0.28 & \\
\hline $\mathrm{PbO}_{2}$ & 0.89 & 4 \\
\hline $\mathrm{Pb}_{3} \mathrm{O}_{4}$ & 2.54 & \\
\hline $\mathrm{HgCl}_{2}^{4}$ & 1.01 & \\
\hline $\mathrm{Hg}_{2} \mathrm{Cl}_{2}$ & 1.75 & \\
\hline $\mathrm{Ag}_{2} \mathrm{SO}_{4}$ & 1.16 (2 hrs.) & 10 \\
\hline $\mathrm{K}_{3} \mathrm{Fe}(\mathrm{CN})_{6}$ & 2.44 (2 hrs.) & 10 \\
\hline $\begin{array}{l}\mathrm{CuSO}_{4} \cdot 5 \mathrm{H}_{2} \mathrm{O} \\
+0.15 \mathrm{M} \mathrm{NH} 3\end{array}$ & 1.85 & \\
\hline
\end{tabular}

1) The stoichiometric amount of oxidant was used.

A detailed study of the more effective oxidants was made by obtaining rate curves for the dissolution of uranium dioxide using the stoichiometric, twice the stoichiometric, and in some tests ten times the stoichiometric quantity of the oxidant. Potassium ferricyanide, silver sulfate and mercuric chloride were found to be extremely rapid oxidants for the dissolution of uranium dioxide. Sodium hypochlorite, potassium peroxydisulfate, and cupric sulfate plus ammonia were found to be good oxidants for the dissolution of uranium dioxide. However, the rates of dissolution with the latter group of chemicals were considerably slower than those obtained with the three chemicals mentioned above. Potassium permanganate was found to be a poor oxidant for the dissolution of uranium dioxide because a coating of manganese dioxide formed on the particles. Hydrogen peroxide decomposed too rapidly to be effective. A discussion of the results obtained for each of these oxidants is presented on the following pages. The prices quoted for these chemicals were taken 
from the "Chemical and Engineering News"Quarterly Report of March 1957, and are presented to be used only as an approximate guide in evaluating the effectiveness of the various oxidants。

\section{Potassium Ferricyanide}

$$
\mathrm{UO}_{2}+2 \mathrm{Fe}(\mathrm{CN})_{6}^{-3}=\mathrm{UO}_{2}^{++}+2 \mathrm{Fe}(\mathrm{CN})_{6}^{-4}
$$

Equivalent Weight $=329$

Cost per pound $=\$ 0.63$

The theoretical amount necessary to oxidize one gram of uranium dioxide is 2.44 grams. Rate curves for the dissolution of uranium dioxide using potassium ferricyanide as the oxidant are presented in Figure 1 . The rate of dissolution of uranium dioxide with potassium ferricyanide was found to be more rapid than with any of the other oxidants tested. When the stoichiometric amount of reagent was used, dissolution was complete within two hours, while when a 100\% excess of the reagent was used, dissolution was complete within thirty minutes. This oxidant has the disadvantage that the reduction of the ferricyanide to the ferrocyanide produces only a one electron change which results in a high equivalent weight, thereby making necessary the use of large amounts of the reagent.

\section{Silver Sulfate}

$$
\mathrm{UO}_{2}+\mathrm{AgSO}_{4}=\mathrm{UO}_{2}^{++}+2 \mathrm{Ag}+\mathrm{SO}_{4}=
$$

Equivalent Weight $=156$

Cost per pound $\approx \$ 29.00$

The theoretical amount necessary to oxidize one gram of uranium dioxide is 1.16 grams. Rate curves for the dissolution of uranium dioxide using silver sulfate as the oxidant are presented in Figure 2. These curves show silver sulfate to be an excellent oxidant for the dissolution of uranium dioxide. The presence of a residue remaining in the leaching flask indicated that the silver salt was reduced down to the metal according to the above reaction. This reagent has the disadvantages that it has a high equivalent weight and is extremely expensive. 


\section{Mercuric Chloride}

$$
\mathrm{UO}_{2}+\mathrm{Hg} \mathrm{Cl} 2=\mathrm{UO}_{2}^{++}+\mathrm{Hg}+2 \mathrm{Cl}^{-}
$$

Equivalent Weight $=136$

Cost per pound $=\$ 4.78$

The theoretical amount necessary to oxidize one gram of uranium dioxide is 1.01 grams. Rate curves for the dissolution of uranium dioxide using mercuric chloride as the oxidant are presented in Figure 3. When the theoretical amount of oxidant was used, the initial rate was rapid but this rate slowed down noticeably after about 80 per cent of the uranium dioxide was dissolved, indicating that at least some excess of the reagent is necessary to maintain a rapid rate of dissolution. When an excess of the oxidant was used, complete dissolution was obtained within two hours. The residue remaining in the flask indicated that the mercuric salt was reduced to metallic mercury. As was the case with the silver salt, this reagent has a high equivalent weight and is costly.

\section{Copper Sulfate plus Ammonia}

$$
\mathrm{UO}_{2}+2 \mathrm{Cu}\left(\mathrm{NH}_{3}\right)_{4}^{++}+2 \mathrm{H}_{2} \mathrm{O}=\mathrm{UO}_{2}^{++}+2 \mathrm{Cu}\left(\mathrm{NH}_{3}\right)_{2}^{+}+2 \mathrm{NH}_{4} \mathrm{OH}
$$

Equivalent Weight $=250\left(\right.$ for $\left.\mathrm{CuSO}_{4} \cdot 5 \mathrm{H}_{2} \mathrm{O}\right)$

Cost per pound $=$ $\$ 0.13$ for $\mathrm{CuSO}_{4} \cdot 5 \mathrm{H}_{2} \mathrm{O}$ $\$ 0.05$ for $\mathrm{NH}_{3}$

Copper alone was found to be a poor oxidant for the dissolution of uranium dioxide. When the copper was complexed with ammonia, a substantial increase in the rate of dissolution was observed. Still the rate was considerably slower than that obtained with the other oxidants discussed above. Assuming a one electron change in the reduction of the cupric ammonia complex to the cuprous ammonia complex, 1.84 grams of cupric sulfate is the theoretical amount necessary to oxidize one gram of uranium dioxide. The reduced form of the species, the cuprous ammonia complex, is oxidized by air according to the following reaction:

$$
2 \mathrm{Cu}\left(\mathrm{NH}_{3}\right)_{2}^{+}+2 \mathrm{NH}_{4} \mathrm{OH}+1 / 2 \mathrm{O}_{2}=2 \mathrm{Cu}\left(\mathrm{NH}_{3}\right)_{4}^{++}+2 \mathrm{OH}^{-}+\mathrm{H}_{2} \mathrm{O} \text {. }
$$

Therefore, the initial concentration of the oxidized species added should remain unchanged and suitable dissolution should be obtained with less than a stoichiometric amount of the reagent. In such a system the copper ammonia ions would be acting 
as a catalyst for air oxidation. Rate curves for the dissolution of uranium dioxide were obtained using $3.68,1.84,0.196$, and 0.098 grams of cupric sulfate in a solution containing 0.15 mole of ammonia. These curves are presented in Figure 4. As can be seen, increasing the copper concentration increases the rate of dissolution, but the increase in rate is not nearly proportional to the increase in concentration. When only about five per cent of the theoretical amount, 0.098 grams of copper sulfate was used, a steady rate of dissolution was obtained with no slowing down of the rate. This would indicate that the initial concentration of the oxidant was being maintained through reoxidation by air.

The copper-ammonia oxidant has the important advantage that both the oxidized and reduced species remain in solution and that the spent oxidant can be constantly regenerated by air, thereby maintaining the initial concentration of the oxidant throughout the leach. This then permits the use of small quantities of the reagent which automatically implies reduced cost.

Sodium Hypochlorite

$$
\mathrm{UO}_{2}+\mathrm{ClO}^{-}+\mathrm{H}_{2} \mathrm{O}=\mathrm{UO}_{2}^{++}+\mathrm{Cl}^{-}+2 \mathrm{OH}^{-}
$$

Equivalent Weight $=37.2$

Cost per pound $=\$ 0.04-\$ 0.07$

The theoretical amount necessary to oxidize one gram of uranium dioxide is 0.28 gram. Rate curves for the dissolution of uranium dioxide using sodium hypochlorite as the oxidant are presented in Figure 5. These curves show sodium hypochlorite to be a good oxidant for the dissolution of uranium dioxide, however, the rates produced are not as rapid as those obtained with some of the oxidants previously discussed. The rate of dissolution was shown to be markedly dependent upon the concentration of hypochlorite used.

Hypochlorite has the advantage of combining low cost with a low equivalent weight. The cost of this reagent has been based on the price of chlorine gas, assuming chlorine gas in carbonate solution would disproportionate according to the following reaction:

$$
\mathrm{Cl}_{2}+\mathrm{OH}^{-}=\mathrm{OCl}^{-}+\mathrm{H}^{+}+\mathrm{Cl}^{-}
$$

The use of hypochlorite as an oxidant would result in a chloride ion buildup in the recycled leach solution and could lead to corrosion problems. The presence of large amounts of chloride in the pregnant leach solution would eliminate the possibility of uranium recovery by alkaline ion exchange. 
Potassium Peroxydisulfate

$$
\mathrm{UO}_{2}+\mathrm{S}_{2} \mathrm{O}_{8}=\mathrm{uO}_{2}^{++}+2 \mathrm{SO}_{4}=
$$

Equivalent Weight $=135$

Cost per pound $=\$ 0.19$

The theoretical amount necessary to oxidize one gram of uranium dioxide is 1.0 gram. Rate curves for the dissolution of uranium dioxide using potassium peroxydisulfate as the oxidant are presented in Figure 6. These curves show that the rate of dissolution using peroxydisulfate is extremely similar to what was obtained when hypochlorite was used. Also, as in the case of hypochlorite, a marked dependence on the concentration of oxidant used was observed. Potassium peroxydisulfate has a higher equivalent weight than sodium hypochlorite and, in addition, is somewhat more expensive. However it does not have the disadvantages associated with hypochlorite.

\section{Potassium Permanganate}

$$
3 \mathrm{UO}_{2}+2 \mathrm{MnO}_{4}^{-}+4 \mathrm{H}_{2} \mathrm{O}=3 \mathrm{UO}_{2}^{++}+2 \mathrm{MnO}_{2}+8 \mathrm{OH}^{-}
$$

Equivalent Weight $=52.7$

Cost per pound $=\$ 0.29-\$ 0.31$

The theoretical amount necessary to oxidize one gram of uranium dioxide is $0.39 \mathrm{gram}$. Rate curves for the dissolution of uranium dioxide using potassium permanganate as the oxidant are presented in Figure 7\% As can be seen, the initial rate of dissolution is rapid with only a small dependence upon the concentration of permanganate used. However, the rate levels off quickly and then proceeds at a rate independent of the permanganate concentration and approximately equal to what would be expected without the presence of a chemical oxidant. Examination of the residue remaining in the reaction flask after leaching showed a distinctly black color instead of the usual brownish color of uranium dioxide. It was postulated that the rapid leveling off of the rate curves was due to a surface coating of manganese dioxide on the undissolved uranium dioxide. In order to substanitate this belief, a test was made using 0.78 gram of potassium permanganate per gram of uranium dioxide. During this test, the uranium dioxide was removed from the leach solution after 30 minutes and again after two hours, and treated with a solution of oxalic acid. After this treatment which would remove any manganese dioxide from the surface of the uranium dioxide, it was returned to the carbonate leach solution. The rate curve obtained in this manner 
and presented in Figure 8 would appear to verify the theory of the manganese dioxide coating. An examination of this curve shows that the surface regeneration results in a sharp rise in the rate of dissolution followed by a leveling off as soon as the manganese dioxide has a chance to recoat the uraniun dioxide surface. When this double regeneration of the surface was made, 88 per cent dissolution was obtained after four hours as compared to only 80 per cent dissolution without a regeneration step.

To determine how effectively attrition would be able to remove this coating of manganese dioxide from the surface of the uranium dioxide the following test was made: one gram of $\mathrm{UO}_{2}$ was leached with 0.78 gram of $\mathrm{KMnO}_{4}$ in the presence of coarse beach sand at 50\% solids. The rate curve obtained is presented in Figure 9. The attrition caused by the beach sand resulted in a more rapid rate of dissolution. Although an improvement in the rate was observed, it should be noted that a leveling off of the rate still occurred. Even after five hours, only 92 per cent of the uranium dioxide was dissolved, a considerably slower rate than would be expected from an observation of the rate over the first fifteen minutes.

Hydrogen Peroxide

$$
\mathrm{UO}_{2}+\mathrm{HO}_{2}^{-}+\mathrm{H}_{2} \mathrm{O}=\mathrm{UO}_{2}^{++}+3 \mathrm{OH}^{-}
$$

Equivalent Weight $=17.0$

Cost per pound $\left(50 \% \mathrm{H}_{2} \mathrm{O}_{2}\right)=$ $\$ 0.26-\$ 0.29$

The theoretical amount necessary to oxidize one gram of uranium dioxide is 0.13 gram. Rate curves for the dissolution of uranium dioxide using hydrogen peroxide as the oxidant are presented in Figure 10. When 1.3 grams or 10 times the stoichiometric amount of hydrogen peroxide was used, complete dissolution of the uranium dioxide was obtained within two hours. When lesser amounts of the oxidant were used, the initial rate was rapid but the oxidation slowed down considerably after the first surge and proceeded at a rate approximately equal to what would be expected without an oxidant. The extent to which the dissolution took place prior to the leveling off of the rate curve was a function of the amount of oxidant added. This behavior is probably due to the fact that this reagent decomposes rapidly. 


\section{CONBINATIONS OF OXIDANTS}

A study was made to determine if small amounts of the more expensive yet highly effective oxidants would catalyze the oxidation of uranium dioxide by cheap but less effective oxidants. It was hoped that only a small amount of the highly effective, expensive reagent could be used if it were constantly regenerated with a cheap, secondary oxidant. Tests were made using small quantities of mercuric chloride, silver sulfate, copper sulfate, and potassium ferricyanide in the presence of excess amounts of sodium hypochlorite, potassium persulfate, and potassium permanganate. A discussion of the results obtained are presented below.

\section{Catalysis of Sodium Hypochlorite}

Tests were made using $50 \mathrm{mg}$ of mercuric chloride, silver sulfate, copper sulfate, and potassium ferricyanide in order to catalyze oxidation of uranium dioxide by sodium hypochlorite. Excess hypochlorite, 0.56 gram per gram of uranium dioxide, was used in each test. The rate curves obtained when mercuric chloride, silver sulfate, and copper sulfate were used are presented in Figure 11. These curves show that each of these reagentscatalyzes the sodium hypochlorite oxidation of uranium dioxide. Complete dissolution was obtained within three hours using either the mercuric or silver salt, while 83 per cent was dissolved using the copper salt compared to only 75 per cent using sodium hypochlorite alone. Inspection of the reaction flask showed that both the mercury and copper remained in solution, while some of the silver salt appeared to have been either reduced to metallic silver or precipitated as silver chloride.

The addition of $50 \mathrm{mg}$ of potassium ferricyanide to the sodium hypochlorite resulted in an increase in the initial rate of dissolution but had an adverse effect on the over-all rate. To determine if increasing the ferricyanide concentration would alter this effect, a test was made using $50^{\circ} \mathrm{mg}$ of potassium ferricyanide added to the sodium hypochlorite. This increase in the ferricyanide concentration resulted in a rapid rate of dissolution up to about 80 per cent, after which the rate slowed down noticeably. This would indicate that a phenomenon was taking place similar to that observed with the smaller amount of ferricyanide. The rate curves obtained in these tests are presented in Figure 12. The results would seem to indicate that the rate slows down because the ferricyanide ion, the oxidizing species, no longer exists 
in solution. Inspection of the leaching flask showed no precipitate of ferric hydroxide, therefore, it must be concluded that in the presence of excess hypochlorite the ferrio cyanide is slowly being converted to some other solubie species which does not oxidize uranium dioxide rapidly. The above results clearly indicated that ferricyanide cannot be used to catalyze the oxidation of uranium dioxide by hypochlorite.

\section{Catalysis of Potassium Peroxydisulfate}

Tests were made using $50 \mathrm{mg}$ of mercuric chloride, silver sulfate, and potassium ferricyanide in order to catalyze the oxidation of uranium dioxide by potassium peroxydisulfate. Excess potassium peroxydisulfate,2,00 grams per gram of uranium dioxide was used in each test. The rate curves obtained are presented in Figure 13. Mercuric chloride was shown to be an effective catalyst with dissolution of uranium dioxide being complete within three hours. Silver sulfate is shown to be a poor catalyst, while with potassium ferricyanide an effect similar to that observed with sodium hypochlorite resulted but to a much lesser extent.

\section{Catalysis of Potassium Permanganate}

Tests were made using $50 \mathrm{mg}$ of mercuric chloride and potassium ferricyanide in order to catalyze the oxidation of uranium dioxide by potassium permanganate. Excess potassium permanganate, 0.78 gram per gram of uranium dioxide, was used in each test. The rate curves obtained are presented in Figure 14. The only effect noted as a result of the addition of these reagents was a small increase in the initial rate of dissolution. Apparent $\mathrm{ly}_{2}$ the surface coating caused by the manganese dioxide was still the controlling factor in the overall rate.

\section{REGENERATION OF FERRICYANIDE BY HYPOCHIORITE}

Potassium ferricyanide had been shown to be the most efficient oxidant for the dissolution of uranium dioxide. . The reduced. species, ferrocyanide, would remain in the carbonatewbicarbonate solution after precipitation of uranium. Therefore, the possibility of regenerating the ferrocyanide in the recycled barren solution by a relatively cheap oxidant such as hypochlorite was considered.

It was felt that it might be possible through the use of only a stoichiometric quantity of sodium hypochlorite to convert ferrocyanide to ferricyanide with little or no degradation of 
the oxidizing species. In order to test this possibility the following experiment was performed:

To a solution at $70^{\circ} \mathrm{C}$ containing 0.5 mole of sodium carbon ate and 0.5 mole of sodium bicarbonate, 3.70 grams of $\mathrm{K}_{3} \mathrm{Fe}(\mathrm{CN})_{6}$ and 1 gram of $\mathrm{UO}_{2}$ were added. The solution was continuously agitated and samples removed at various intervals. After each hour, 1 gram of $\mathrm{NO}_{2}$ and 0.28 gram of $\mathrm{NaOCl}$ (the theoretical amount necessary to oxidize 1 gram of $\mathrm{UO}_{2}$ ) were added to the solution.

Rate curves for the dissolution of each successive gram of uranium dioxide added are presented in Figure 15. As can be seen, there is only a small difference between the rate of dissolution for the first gram and the fifth gram of uraniun dioxide added. These results indicate that the greater portion of the ferricyanide can be regenerated by the sodium hypochlorite and recycled for the dissolution of uranium dioxide. 


\section{TESTS ON ORE SAMPLES}

\section{BREITATNARY EVALUATION OF' OXIDANTS}

The investigation of the effect of the various oxidants on the rate of dissolution of uranium dioxide had indicated that several oxidation systems might be of practical use in the recovery of uranium from ores by carbonate leaching. Therefore, a study was made to determine the rate of dissolution of uranium firom ore samples using the following oxidents:

(1) Potassium Permanganate - Although permanganate was shown to be a poor oxidant for the dissolution of uranium dioxide, it has been generally reported and accepted to be the most effective oxidant for use in the dissolution of uranium from ores by carbonate leaching $(2,8,9)$. There fore, the data obtained using permanganate will be used to evaluate the effectiveness of the other oxidants tested.

(2) Copper-Ammonia Reagent - Although not one of the more rapid oxidants for uranium dioxide, the combination of copper and ammonia has the important advantage that the oxidizing species is regenerated by air. As a result, the cupric ammonia complex ion is simply acting as a catalyst for air oxidation, thereby making possible the use of small amounts of the reagent while maintaining oxidizing conditions through out the entire leaching period. This is not true with the other chemical oxidants tested. These reagents are consumed by oxidizable substances other than uranium within several hours or less of leaching time and are not regenerated by air. Any oxidation which takes place thereafter is the rem sult of air oxidation which is known to be slow.

(3) Potassium Ferricyanide whis reagent was the most effective oxidant tested for the dissolution of uranium dioxide. Also, it was shown that the oxidizing species could be regenerated by sodium hypochlorite and used again. If this same procedure could be adapted to the leaching of ores, then we would be able to take advantage of the rapid oxidizing power of ferricyanide at an economical cost.

(4) Sodium Hypochlorite - This reagent is by far the most economical per equivalent of oxidizing power and therefore could be used in large quantities. 
(5) Sodium Hypochlorite plus Mercuric Chloride - Mercuric chloride catalyzed the sodium hypochlorite oxidation of uranium dioxide and should do likewise for the oxidation of uranium in ores.

The following procedure was used in testing these oxidants: Minus 65-mesh E. L. Cord Ore, Sample 365-1, was leached at $85^{\circ} \mathrm{C}$ and 40 per cent solids with a solution containing 50 grams of sodium carbonate and 20 grams of sodium bicarbonate per liter. Air at a rate of $10-20 \mathrm{cc}$ per minute was introduced into the pulp through a frit。 Samples were re. moved after 1, 2, 4, 7 and 23 hours and the residues analyzed for uranium. Results of these tests are presented in Table III on the following page.

The use of air as the only oxidant resulted in only 73.2 per cent extraction of uranium in seven hours, and as expected the addition of each of the chemical oxidants resulted in considerable improvement over the air oxidation. The usual increase in the rate of dissolution of uranium with increas ing amounts of oxidant was observed.

The copper-ammonia reagent appears to be the most effective oxidant based on both oxidizing capacity and cost. The use of 8 lbs per ton cupric sulfate and 8 lbs per ton of ammonia resulted in more efficient dissolution of uranium than 10 lbs per ton of permanganate and would cost only about $\$ 1.50$ per ton of ore as compared to about $\$ 3.00$ per ton of ore for the permanganate.

The effect of potassium ferricyanide may be evaluated by comparing the test made with $60 \mathrm{lbs}$ per ton of potassium ferricyanide with the test made with 10 lbs per ton of potassium permanganate since these concentrations are approxio mately equivalent in oxidizing capacity. The initial rate of dissolution was more rapid with permanganate; but after four hours, the ferricyanide reagent was more effective, and at the end of seven hours, 96.6 per cent extraction pas obtained with ferricyanide as compared to 93.5 per cent with permanganate. It was observed that all of the permanganate was consumed within one hour, and any further dissolution that takes place results from the air oxidation of the reduced uranium. If we assume that a similar consumption of the oxidant takes place with the ferricyanide, and spot tests seem to indicate that it does, then we may postulate that after the first hour the slower rate of dissolution of uranium observed in the leach to which permanganate had been added is due to a coating of manganese dioxide on the reduced uranium, thereby slowing down the rate of air oxidation. Although potassium ferri- 


\section{1}

\section{Table III}

Comparison of Oxidants for Use in Carbonate Leaching

E. L. Cord, Sample 365-1, U308 $=0.612 \%$

\begin{tabular}{|c|c|c|c|c|c|c|c|c|c|c|c|c|c|c|}
\hline \multirow{3}{*}{$\begin{array}{l}\text { Leaching } \\
\text { Time } \\
\text { in Hours }\end{array}$} & \multirow[b]{3}{*}{ Air } & \multicolumn{11}{|c|}{ \% U308 Extraction } & & \\
\hline & & \multicolumn{3}{|c|}{$\begin{array}{l}\mathrm{KMnO}_{4} \\
\mathrm{Lbs} / \mathrm{Ton}\end{array}$} & \multicolumn{2}{|c|}{$\begin{array}{c}\mathrm{CuSO}_{4} \cdot 5 \mathrm{H}_{2} \mathrm{O}_{+} \\
0.15 \mathrm{M} \text { NH } 4 \mathrm{OH} \\
\mathrm{Lbs} / \mathrm{Ton}\end{array}$} & \multicolumn{4}{|c|}{$\begin{array}{c}\mathrm{K}_{3} \mathrm{Fe}(\mathrm{CN})_{6} \\
\mathrm{Lbs} / \mathrm{Ton}\end{array}$} & \multicolumn{2}{|c|}{$\begin{array}{c}\mathrm{NaOCl} \\
\mathrm{Lbs} / \mathrm{Ton}\end{array}$} & \multicolumn{2}{|c|}{$\begin{array}{c}\mathrm{NaOCl}+\mathrm{HgCl}_{2} \\
\mathrm{Lbs} / \mathrm{Ton} \\
\end{array}$} \\
\hline & & 5 & 10 & 20 & 0.8 & 8 & 20 & 40 & 60 & 80 & 10 & 40 & $10+0.2$ & $40+0.8$ \\
\hline 1 & 35.1 & 70.9 & 81.9 & 91.2 & 69.8 & 82.0 & 69.8 & 75.7 & 76.5 & 79.7 & 55.4 & 91.0 & 62.4 & 95.3 \\
\hline 2 & 41.0 & 77.9 & 85.9 & 91.7 & 82.5 & 91.8 & 78.4 & 82.0 & 83.8 & 87.1 & 67.2 & 95.4 & 73.3 & 96.7 \\
\hline 4 & 63.9 & 85.8 & 90.2 & 93.6 & 90.4 & 94.9 & 88.2 & 91.2 & 93.0 & 95.1 & 77.5 & 97.3 & 84.5 & 97.8 \\
\hline 7 & 73.2 & 90.5 & 93.5 & 95.6 & 93.6 & 96.9 & 93.5 & 95.3 & 96.6 & 97.4 & 86.6 & 97.4 & 89.9 & 98.0 \\
\hline 23 & 95.8 & 96.6 & 97.2 & 97.4 & 97.1 & 98.2 & 96.6 & 98.2 & 97.8 & 98.0 & 93.0 & 98.0 & 95.3 & 97.8 \\
\hline
\end{tabular}


cyanide is an efficient oxidizing agent, it is more expensive than the copperammonia reagent even if it is assumed that the reagent can be regenerated with sodium hypochlorite in the barren leach solution.

Sodium hypochlorite at a concentration of $40 \mathrm{lbs}$ per ton of ore caused a rapid rate of dissolution of the uranium. This quantity of hypochlorite has over three times the oxidizing capacity as 20 lbs per ton of permanganate and would cost considerably less. When $0.8 \mathrm{lb}$ per ton mercuric chloride was added to 40 lbs per ton of sodium hypochlorite, 95 per cent of the uranium was dissolved in one hour. This is by far the most rapid rate obtained with any of the oxidants. Unfortunately, analysis of the filtrate showed no presence of mercuric or mercurous ions. Unless the mercury remained in the barren solution to be recycled to the next leach, the use of even small amounts of mercuric chloride at $\$ 4.78$ per Ib. would be uneconomical.

\section{DETAILED STUDY OF COPPER-AMMONIA BEACENT}

Since the cupric-ammonia reagent had been shown to be both an efficient and economical oxidant for use in the dissolution of uranium from ores, the remainder of this investigation was concerned with a more detalled study of some of the factors which would affect the efficiency of this reagent. The following procedure was used in all of the following leaching tests unless specified otherwise: Minus 65-mesh LaSal ore (a composite of Sample Numbers 189-3-5-6-7-8) was leached at $85^{\circ} \mathrm{C}$ and 40 per cent solids with a solution containing 50 grams of sodium carbonate and 20 grams of sodium bicarbonate per liter. Air at a rate of 10-20 cc per minute was introduced into the pulp by means of a frit. Samples were removed after $1,2,4,6$ and 23 hours and the residues analyzed for uranium while the filtrates were analyzed for copper.

\section{Copper Concentration}

To determine the effect of the copper concentration on the rate of dissolution of uranium, tests were made using 1,2 , 4, 6 , and $8 \mathrm{lbs}$ per ton of cupric sulfate with 8 lbs per ton of ammonia. For comparison purposes, tests were also made using air alone and $12 \mathrm{lbs}$ per ton of potassium permanganate. Results of these tests are presented in Table IV on the following page. These results show that after four hours of leaching time, the rate of dissolution of uranium with 1 lb per ton 


\section{3}

\section{Table IV}

Effect of Copper Concentration on the Rate of Dissolution of Uranium

La Sal Ore, Composite of Samples 189-3-5-6-7-8 $\quad \mathrm{U}_{3} \mathrm{O}_{8}=0.472 \%$

$\% \mathrm{U}_{3} \mathrm{O}_{8}$ Extraction

\section{Leaching \\ Time}

in Hours

0

236.3

6

23

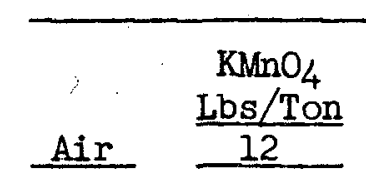

$29.9 \quad 82.2$

$73.9 \quad 75.8$

87.1

82.6

90.3

90.391 .7

91.9

91.995 .396 .0

$$
68.0
$$

96.6

97.7

$98.3 \quad 98.7$

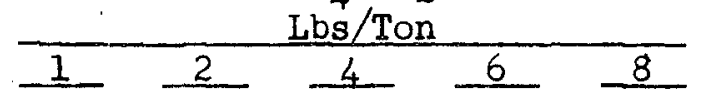

78.2

98.
Filtrate, $\mathrm{g} / 1$ Copper

$\mathrm{CuSO}_{4} .5 \mathrm{H}_{2} \mathrm{O}$ $\mathrm{Lbs} / \mathrm{Ton}$

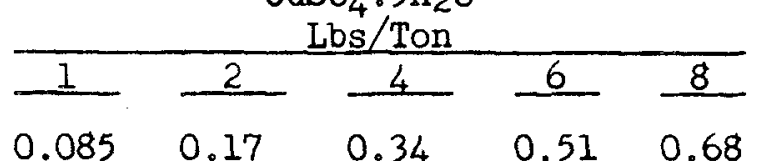

$\begin{array}{lllll}0.085 & 0.17 & 0.34 & 0.51 & 0.68\end{array}$

$\begin{array}{lllll}0.028 & 0.063 & 0.15 & 0.21 & 0.30\end{array}$

$\begin{array}{lllll}0.026 & 0.056 & 0.13 & 0.19 & 0.27\end{array}$

1/ Eight pounds per ton of ammonia used in these tests. 
of cupric sulfate is equal to the rate of dissolution with 12 lbs per ton of potassium permanganate. Increasing the copper concentration increases the rate of dissolution, although increasing the concentration above 4 lbs per ton resulted in only a small increase in the leaching rate. Analyses of the leach solutions indicated that about 55 to 65 per cent of the copper added to the leach solution was precipitated during the first hour of leaching and the remaining copper was only slowly precipitated during subsequent lèaching.

Precipitation tests showed that any copper remaining in the pregnant solution was precipitated with the uranium. Yellow cakes assayed approximately 78 per cent $\mathrm{U}_{3} \mathrm{O}_{8}$ and between 0.2 and 3.1 per cent copper depending upon the amount of copper present in the pregnant solution. Although the copper specification was exceeded in some of these products, it is only by a slight amount and would have very little effect in the subsequent refinery processing.

\section{Ammonia Concentration}

To determine the effect of the ammonia concentration on the rate of dissolution of uranium, tests were made using 0 , 2, $4,6,8$, and $10 \mathrm{lbs}$ per ton anmonia with 2 lbs per ton of cupric sulfate. Results of these tests are presented in Table $V$ on page 25. These results show that increasing the ammonia concentration increases the rate of dissolution of uranium, although increasing the concentration above 6 lbs per ton results in only a small increase in the leaching rate. This increase in the leaching rate with increase in ammonia concentration can be attributed to the fact that the increased amounts of ammonia keep larger amounts of copper in solution.

\section{Temperature}

To determine the effect of temperature on the rate of dis. solution of uranium, six-hour leaching tests were made at ambient temperature, $50,65,75,85$, and $100^{\circ} \mathrm{C}$ using $4 \mathrm{lbs}$ per ton of cupric sulfate and 8 lbs per ton of ammonia. Results of these tests are presented in Table VI on page 26. 


\section{5}

Table V

Effect of Ammonia Concentration on the Rate of Dissolution of Uranium

La Sal Ore, Composite of Samples 189-3-5-6-7-8, U308 $=0.472 \%$

\begin{tabular}{|c|c|c|c|c|c|c|c|c|c|c|c|c|}
\hline \multirow{3}{*}{$\begin{array}{l}\text { Leaching } \\
\text { Time } \\
\text { in Hours }\end{array}$} & \multicolumn{6}{|c|}{ \% U308 Extraction } & \multicolumn{6}{|c|}{ Filtrate, g/I Copper } \\
\hline & \multicolumn{6}{|c|}{$\mathrm{NH}_{3}, \mathrm{Lbs} / \mathrm{Ton}$} & \multicolumn{6}{|c|}{$\mathrm{NH}_{3}$, Lbs/Ton } \\
\hline & 0 & 2 & 4 & 6 & 8 & 10 & 0 & 2 & 4 & 6 & 8 & 10 \\
\hline 1 & 71.4 & 74.8 & 78.6 & 77.6 & 75.8 & 78.2 & 0.012 & 0.031 & 0.050 & 0.053 & 0.063 & 0.066 \\
\hline 2 & 74.8 & 81.6 & 83.9 & 83.9 & 83.5 & 83.7 & 0.011 & 0.025 & 0.047 & 0.047 & 0.056 & 0.057 \\
\hline 4 & 81.4 & 82.8 & 90.9 & 92.8 & 91.7 & 93.6 & 0.010 & 0.022 & 0.043 & 0.041 & 0.055 & 0.054 \\
\hline 6 & 86.9 & 89.6 & 93.6 & 94.7 & 95.3 & 95.8 & 0.010 & 0.020 & 0.040 & 0.040 & 0.054 & 0.050 \\
\hline 23 & 96.6 & 98.1 & 98.1 & 98.7 & 98.7 & 98.7 & 0.007 & 0.013 & 0.026 & 0.027 & 0.035 & 0.042 \\
\hline
\end{tabular}

1/ Two pounds per ton of $\mathrm{CuSO}_{4} \cdot 5 \mathrm{H}_{2} \mathrm{O}$ used in these tests. 


\section{Table VI}

Effect of Temperature on the Copper-Ammonia Oxidant

Composite of Samples 189-3-5-6-7-8; U308 $=0.472 \%$

\begin{tabular}{c}
$\begin{array}{c}\text { Temperature } \\
\text { OC }\end{array}$ \\
\hline Amb \\
50 \\
65 \\
75 \\
85 \\
100
\end{tabular}

\begin{tabular}{c}
$\begin{array}{c}\text { Residue Assay } \\
\% \mathrm{U}_{3} \mathrm{O}_{8}\end{array}$ \\
\hline 0.304 \\
0.118 \\
0.057 \\
0.033 \\
0.019 \\
0.104
\end{tabular}

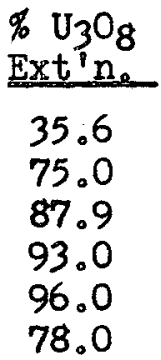

These tests show that increasing the leaching temperature increases the rate of dissolution of uranium. However, when the leaching temperature was raised to $100^{\circ} \mathrm{C}$, there was a marked decrease in the extraction. This is believed to be due to the rapid evolution of ammonia from solution at this elevated temperature and the resultant precipitation of copper. Therefore, without a sufficient amount of the oxidizing species remaining in solution, there was a decrease in the rate of dissolution.

\section{Effect of Sulfate Buildup}

In order to determine the effect of sulfate buildup in a recycled leach solution on the oxidizing power of the cupricammonia oxidant, several leaching tests were made in which known amounts of sulfate were added to the leach solution as sodium sulfate. Results of these tests showed no deleterious effect on the rate of dissolution when up to 45 grams per liter sulfate was added to the leach solution. Other tests made also showed that ammonium sulfate may be substituted as the source of ammonium ions in place of ammonia gas without any significant change in the rate of dissolution.

\section{Copper-Bearing Ore as Source of Copper}

An investigation was made of the possibility than an ore containing copper may be substituted as the source of cupric ions and thus eliminate the necessity of adding cupric sul- 
fate to the leach solution. Copper-bearing White Canyon ore, Sample 324-17, was blended with LaSal ore at a 1-1 ratio and carbonate leaching tests were made with the addition of the following reagents: (1) 8 lbs per ton $\mathrm{NH}_{3}$ (2) 8 lbs per ton $\mathrm{NH}_{3}$ plus 2 lbs per ton $\mathrm{CuSO}_{4} \cdot 5 \mathrm{H}_{2} \mathrm{O}$. These tests were compared to a leaching test in which no reagent was added. Also a 9-I blend of LaSal ore to White Canyon ore was prepared and leached with 8 lbs per ton of ammonia. Results of these tests are presented in Table VII on page 28. These tests show that when the leaching was carried out with the addition of ammonia, a considerable amount of copper was present in the leach liquor. Also a considerable increase in the rate of dissolution was observed when compared to the rate of dissolution when the leach was made without the addition of ammonia, in which case only very small amounts of copper were present in the leach solution. The test in which both copper and ammonia were added with the belief that the addition of some copper would aid in the dissolution of the copper present in the ore showed no significant difference from the test in which only ammonia was added.

\section{Leaching in a Covered Vessel}

Since the evolution of ammonia from the leach solution is an important factor to be considered in the use of the cupric ammonium oxidant, tests were made to compare the effect of leaching in covered or uncovered vessels. Three six hour leaching tests were made: one in which the leaching

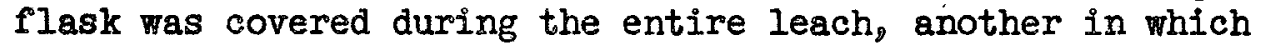
the flask was uncovered during the entire leach, and a third in which the flask was covered during the first four hours and uncovered during the remaining two hours. Results of these tests are presented in Table VIII on page 29. As can be seen, the rate of dissolution of uranium is more rapid when the leaching vessel is kept covered during the entire leach. Covering the flask prevents the rapid evolution of ammonia and keeps a sufficient amount of copper in the leach solution. to ensure a rapid rate of dissolution. Uncovering the flask allows the ammonia to boil of $f_{\text {and }}$ the copper to precipitate with a resultant decrease in the extraction rate. The amount of copper remaining in the pregnant solution when the leaching flask remained covered was 0.11 gram per liter. With a uranium concentration of 3.5 grams $\mathrm{U}_{3} \mathrm{O}_{8}$ per liter, the resultant yellow cake would not meet the copper specification. When the leaching flask was uncovered for the last two hours only, the copper in the 


\section{8}

Table VII

Substitution of an Ore Containing Copper as Source of Cupric Ions

for the Copper Ammonia Oxidant

1 - 1 Blend of White Canyon Ore and La Sal Composite Ore

\begin{tabular}{|c|c|c|c|c|c|c|c|c|}
\hline \multirow{3}{*}{$\begin{array}{l}\text { Leaching } \\
\text { Time } \\
\text { in Hours }\end{array}$} & \multicolumn{8}{|c|}{ Ammonia, Lbs/Ton } \\
\hline & \multicolumn{2}{|c|}{0} & \multicolumn{2}{|r|}{$=$} & \multicolumn{2}{|c|}{81} & \multicolumn{2}{|c|}{82} \\
\hline & 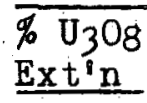 & $\begin{array}{l}\text { Filtrate } \\
\mathrm{g} / \mathrm{I} \mathrm{Cu}\end{array}$ & $\begin{array}{l}\mathrm{U}_{3} \mathrm{O}_{8} \\
\text { Ext'n }\end{array}$ & $\begin{array}{l}\text { Filtrate } \\
\mathrm{g} / 1 \mathrm{Cu}\end{array}$ & $\begin{array}{l}\% \mathrm{U}_{3} 08 \\
\text { Ext'n }\end{array}$ & $\begin{array}{l}\text { Filtrate } \\
\mathrm{g} / \mathrm{Cu}\end{array}$ & $\begin{array}{l}\% U_{3} 0_{8} \\
\text { Extin }\end{array}$ & $\begin{array}{l}\text { Filtrate } \\
\mathrm{g} / 1 \mathrm{Cu}\end{array}$ \\
\hline 1 & - & 0.002 & 64.7 & 0.038 & 71.0 & 0.11 & 47.7 & 0.001 \\
\hline 2 & -- & 0.002 & -- & 0.074 & 78.0 & -- & 58.8 & 0.002 \\
\hline 4 & 70.4 & -- & 85.3 & 0.13 & 87.3 & 0.10 & 68.4 & 0.007 \\
\hline 6 & 78.7 & 0.002 & 92.3 & 0.16 & 91.3 & 0.11 & 84.0 & 0.017 \\
\hline 23 & 88.0 & 0.002 & 97.0 & 0.28 & 96.0 & 0.41 & -- & -- \\
\hline
\end{tabular}

1) Two pounds per ton $\mathrm{CuSO}_{4} \cdot 5 \mathrm{H}_{2} \mathrm{O}$ used in this test.

2/ 9-1 Blend of La Sal ore to White Canyon ore. 
pregnant liquor was reduced to 0.04 gram per liter, an amount which when present in the yellow cake would not exceed specifications. Although exceeding the copper specifications does not represent a serious problem, it should be possible, by keeping the leaching vessel closed during the greater portion of the leaching time, to obtain good extraction and to meet copper specifications by uncovering the vessel for a short period at the end of the leach so as to boil of ammonia and precipitate copper.

\section{Table VIII}

Effect of Leaching in Covered Vessel on the Rate of Dissolution of Uranium Using Copper-Ammonia Oxidant

Composite of LaSal Ore, Samples 189-3-5-6-7-8; $\mathrm{U}_{3} \mathrm{O}_{8}=0.472 \%$

\begin{tabular}{|c|c|c|c|c|c|c|}
\hline \multirow[b]{2}{*}{$\begin{array}{c}\text { Leaching Time } \\
\text { in Hours }\end{array}$} & \multicolumn{2}{|c|}{ Covered Flask } & \multicolumn{2}{|c|}{ Uncovered Flask } & \multicolumn{2}{|c|}{ Covered for $4 \mathrm{hrs}^{1}$} \\
\hline & $\begin{array}{l}\% \mathrm{U}_{3} \mathrm{O}_{8} \\
\mathrm{Ext}_{\mathrm{n}}\end{array}$ & $\begin{array}{l}\text { Filtrate } \\
\mathrm{g} / \mathrm{I} \mathrm{Cu}\end{array}$ & $\begin{array}{l}\% \mathrm{U}_{3} \mathrm{O}_{8} \\
\mathrm{Ext} \mathrm{n}_{\mathrm{n}} \\
\end{array}$ & $\begin{array}{l}\text { Filtrate } \\
\text { g/l Cu }\end{array}$ & $\begin{array}{l}\% \mathrm{U}_{3} \mathrm{O}_{8} \\
\operatorname{Ext}_{n} \\
\end{array}$ & $\begin{array}{l}\text { Filtrate } \\
\mathrm{g} / \mathrm{I} \mathrm{Cu}\end{array}$ \\
\hline 1 & 78.2 & 0.15 & 76.9 & 0.13 & 78.0 & 0.15 \\
\hline 2 & 87.9 & 0.13 & 87.1 & 0.081 & 87.5 & 0.14 \\
\hline 4 & 94.1 & 0.12 & 91.2 & 0.038 & 93.7 & 0.12 \\
\hline 6 & 96.0 & 0.11 & 93.4 & 0.032 & 94.9 & 0.04 \\
\hline
\end{tabular}

1/ Leaching flask covered for first four hours and uncovered for remaining two hours.

\section{Ion Exchange}

Tests were made to determine if the presence of copper in the leach liquor represents an interference in the recovery of uranium by ion exchange. Distribution coefficients for copper and uranium were determined using XE-123 resin and the following leach liquor:

Constituent $\mathrm{U}_{3} \mathrm{O}_{8} \quad \mathrm{Cu} \quad \mathrm{Na}_{2} \mathrm{CO}_{3}$

$\mathrm{NaHCO}_{3}$

Concentration, $g / 1 \quad 0.81 \quad 0.025 \quad 14.9 \quad 4.1$ 
The following distribution coefficients were obtained:

$$
\begin{aligned}
& \mathrm{U}_{3} \mathrm{O}_{8}, \mathrm{Kd}=\frac{\mathrm{g} \mathrm{U}_{3} \mathrm{O}_{8} \text { per lj.ter WSR }}{\mathrm{g} \mathrm{U}_{3} \mathrm{O}_{8} \text { per liter of solution }}=\frac{56.5}{0.24}=235 \\
& \mathrm{Cu}, \mathrm{Kd}=\frac{\mathrm{g} \mathrm{Cu} \text { per liter WSR }}{\mathrm{g} \mathrm{Cu} \mathrm{per} \mathrm{liter} \mathrm{of} \mathrm{solution}}=\frac{0.08}{0.024}=3.0
\end{aligned}
$$

These distribution coefficients show that the absorption of copper on the resin is negligible.

Leaching Tests on Various Ores

In order to determine the versatility of the cupric ammonia reagent as an oxidant for the dissolution of uranium, carbonate leaching tests using 2 lbs per ton cupric sulfate and 8 lbs per ton of ammonia mere made on several ore samples which were chosen because amenability tests reported from this laboratory had indicated the need for use of an oxidant in the alkaline leaching of these ores. Results of these tests are presented in Table IX along with the results previously obtained when amenability tests were made on these ores using air alone and $10 \mathrm{lbs}$ per ton of potassium permanganate as oxidant. These results show that for all the ores tested the copper-ammonia reagent was an effective oxidant. 


\section{Table IX}

Use of Copper Ammonia Reggent as Oxidant in Carbonate Leaching of Various Ores.

Ore Sample

Utex

75-7

Richardson Claim 157-2

Los Ochos

190-1

Ralston Creek

306-1

Ambrosia Lake

$331-26$

Moonlight Claim

364-1

North Alice

367-1

Globe Mining Co. $375-1$

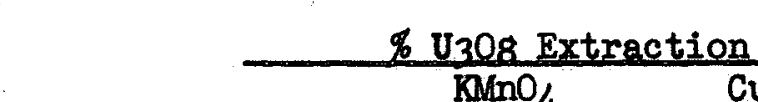

Time Hre Alr $101 \mathrm{bs} / \mathrm{ton}$

89.8

94.5

94.5

6
$24=$

$\begin{array}{rr}6 & - \\ 24 & -\end{array}$

93.5

97.6

94.7

97.8

$6 \quad 30.2$

$89.6^{2 /}$

87.0

97.5

641.5

57.8

59.4

49.7

$24 \quad 53.0$

89.9

94.8

94.6

$6 \quad 82.9$

92.9

88.3

89.1

87.7

$\begin{array}{rr}6 & 54.4 \\ 24 & 71.7\end{array}$

93.3

97.3

97.1

97.6

$\begin{array}{rr}6 & 64.3 \\ 24 & 91.4\end{array}$

6. 84.7

24. 95.6

97.9

96.9

98.2

98.2

I/ $8 \mathrm{lbs} /$ ton $\mathrm{NH}_{3}$ used in these tests.

$2 / 1 \mathrm{bs} /$ ton of $\mathrm{KMnO}_{4}$ 


\section{LITERATURE CITED}

1. Woody, R. J., Grandfield, J. M., U. S. Atomic Energy Commission, MTGEAI10 (1951).

2. Brown, E. G., Ibid., $\mathrm{ACCO}-32$ (1953).

3. Ibid, $A C C O-36$ (1953).

4. McGlone, Po, Chemical Research Laboratory, Teddington, England, CRL/AE 59 (1950).

5. Ibid。, CRL/AE 64 (1950)。

6. Miller, R. P., Napier, E。, Ibid., CRI/AE 68 (1950).

7. Pearson, D。, Ibid。, CRL/AE 81 (1951)。

8. Thunaes, A., Brown, E。 A., Rabbitts, A. To, Canadian Internal Report 1/51 (1951).

9. Hoffman, C. J., Watson, W. I., Schwien, I. F., U. S. Atomic Energy Commission, RMO-2617 (1955).

10. Clifford, W. E, Larkin, E. E, Smith, E。 Mo, Ibid., RMO-2621 (1956). 
FIGURES

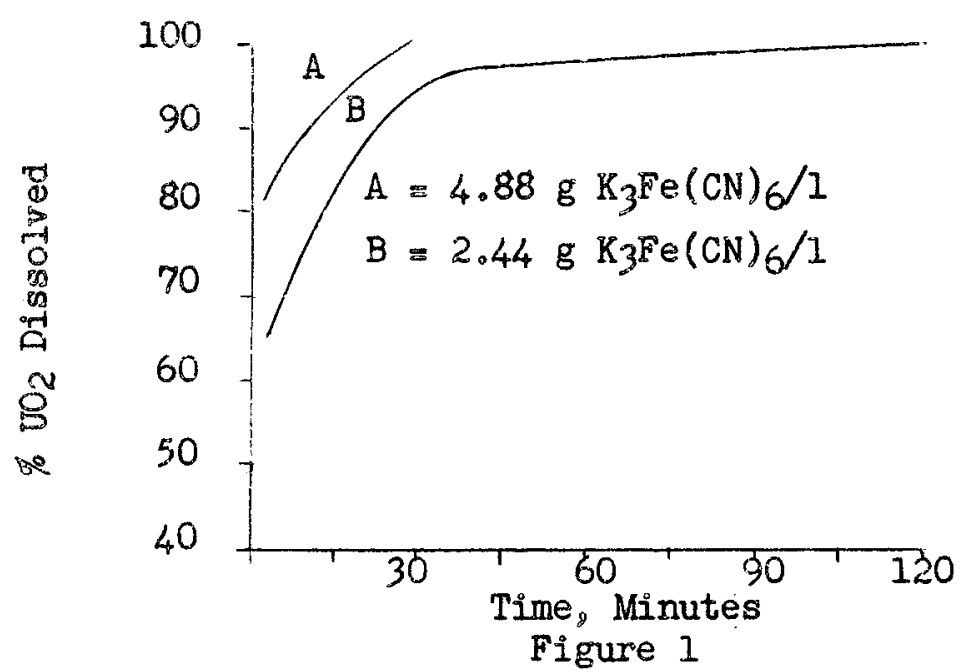

Dissolution of $\mathrm{UO}_{2}$ in Carbonate-Bicarbonate Solution Using $\mathrm{K}_{3} \mathrm{Fe}(\mathrm{CN})_{6}$ as Oxids

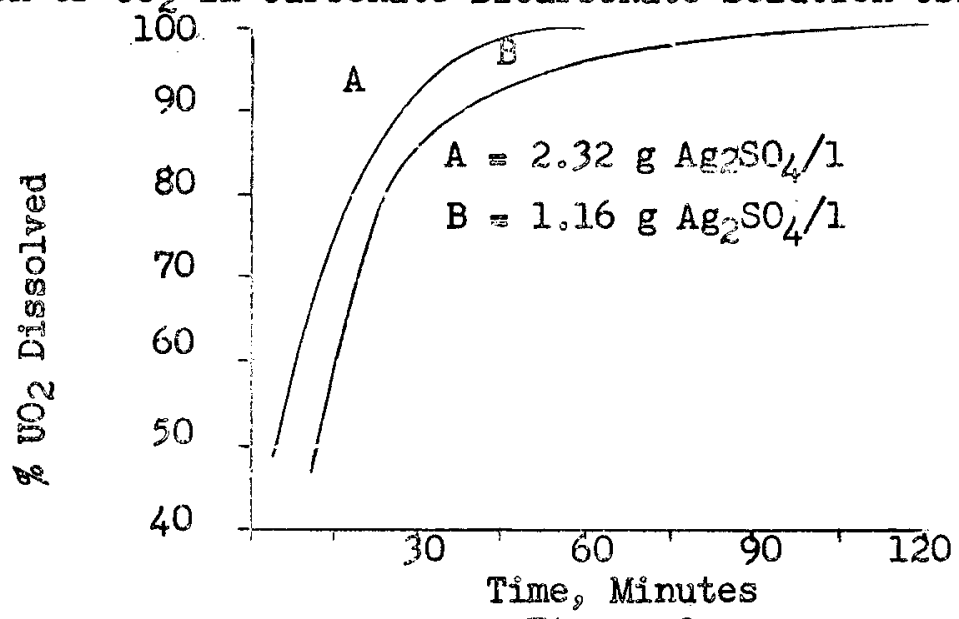

Figure 2

Dissolution of $\mathrm{UO}_{2}$ in Carbonate-Bicarbonate Solution Using $\mathrm{Ag}_{2} \mathrm{SO}_{4}$ as Oxidan

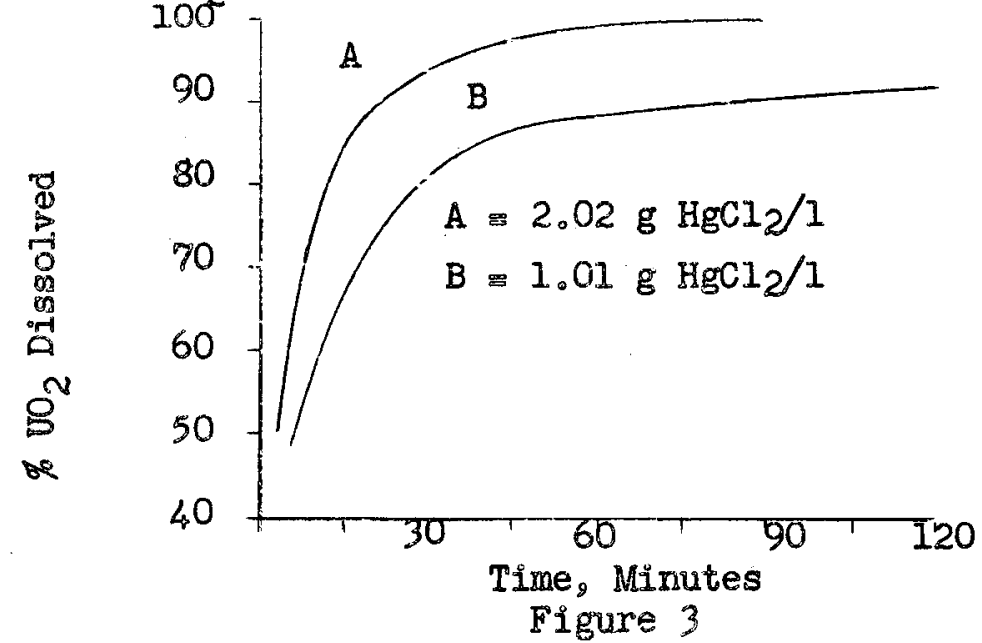

Dissolution of $\mathrm{WO}_{2}$ in Carbonate-Bicarbonate Solution Using $\mathrm{HgCl}_{2}$ as Oxidan 
WIN $=86$

-34 -

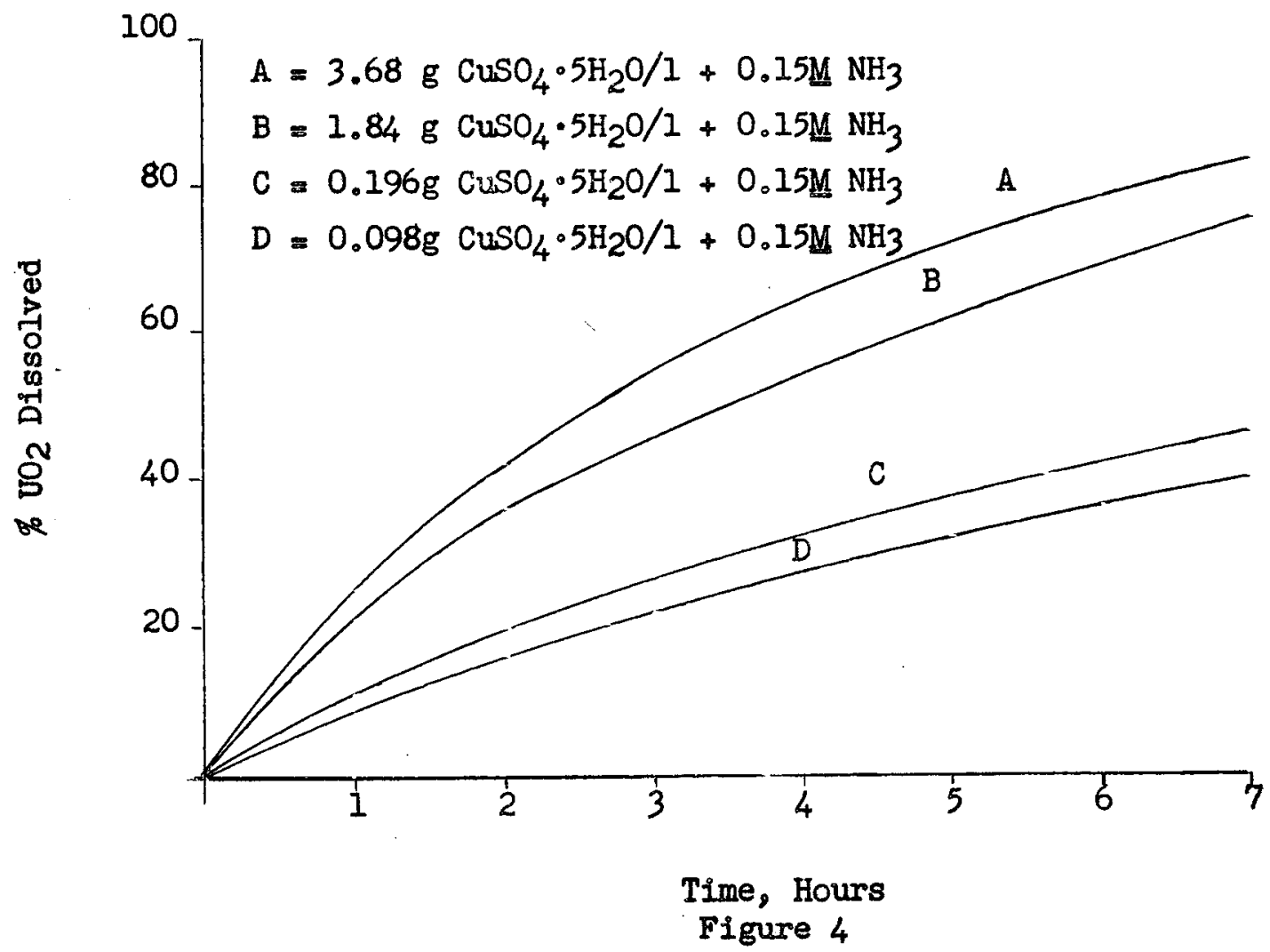

Dissolution of $\mathrm{UO}_{2}$ in Carbonate-Bicarbonate Solution Using Copper-Ammonia Reagent as Oxidant 
WIN-86

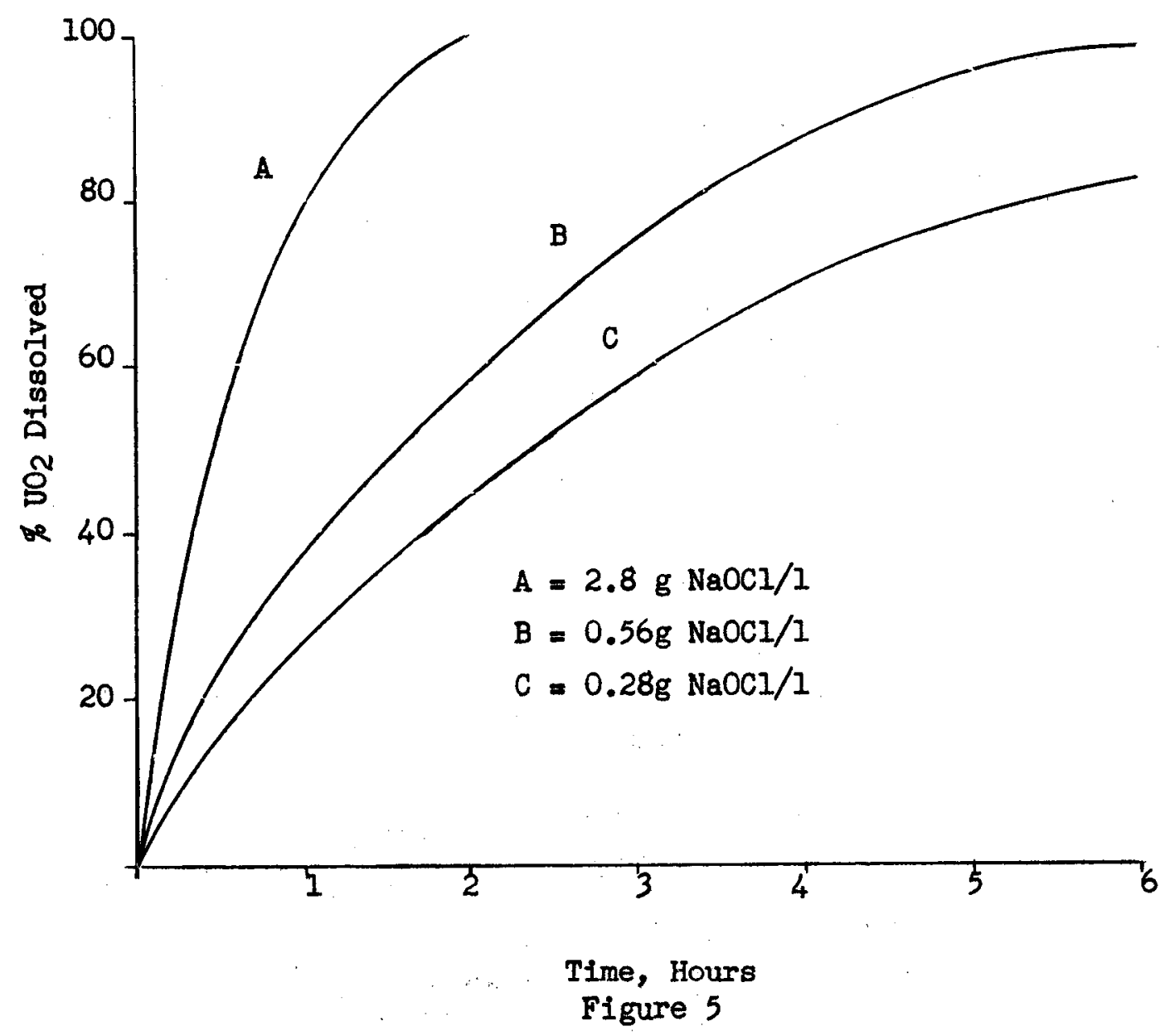

Dissolution of $\mathrm{VO}_{2}$ in Carbonate-Bicarbonate Solution Using $\mathrm{NaOCl}$ as Oxidant 
WIN-86

- 36 -

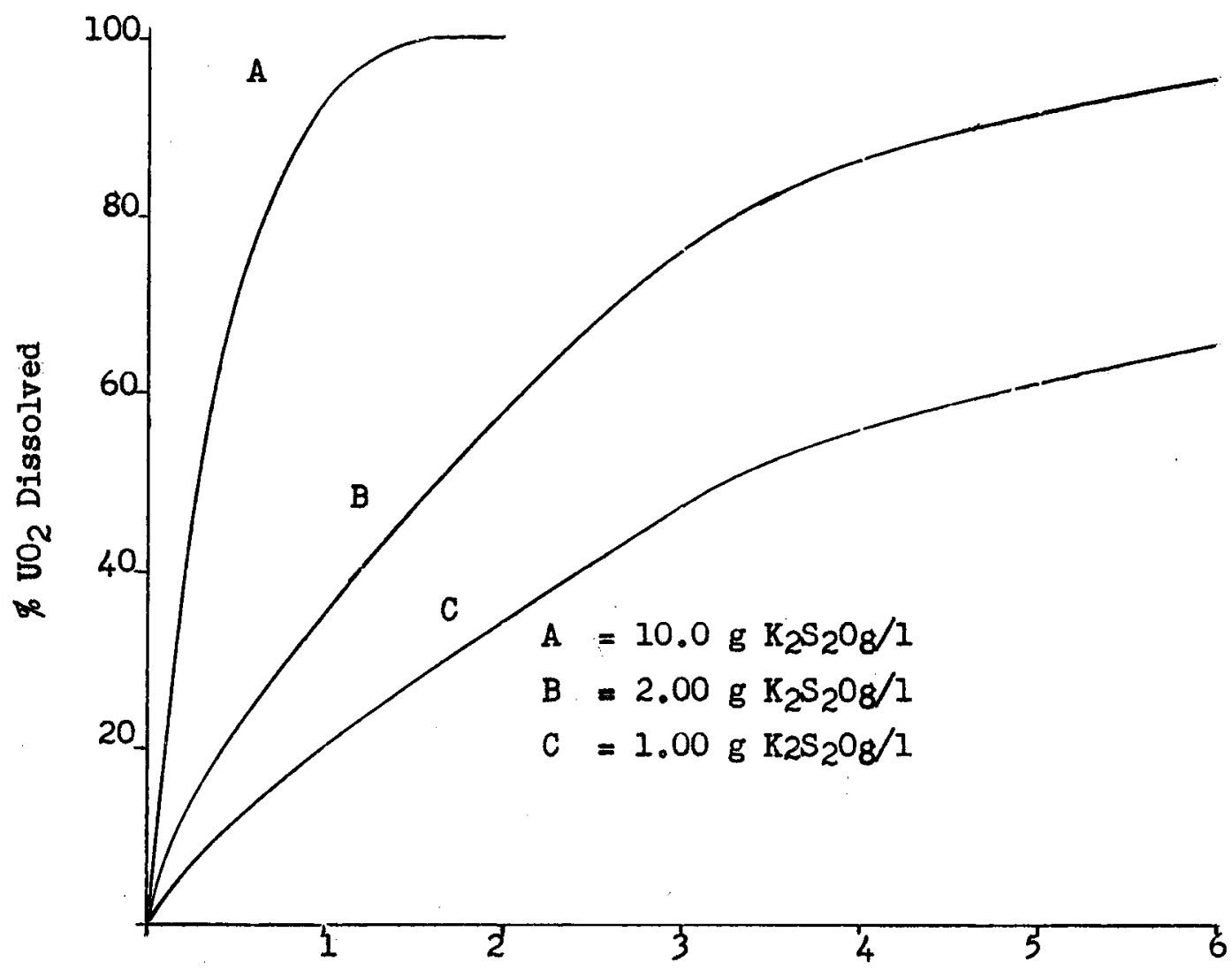

Time, Hours

Figure 6

Dissolution of $\mathrm{UO}_{2}$ in Carbonate-Bicarbonate Solution Using $\mathrm{K}_{2} \mathrm{~S}_{2} \mathrm{O}_{8}$ as Oxidant 
WIN-86

- 37 -

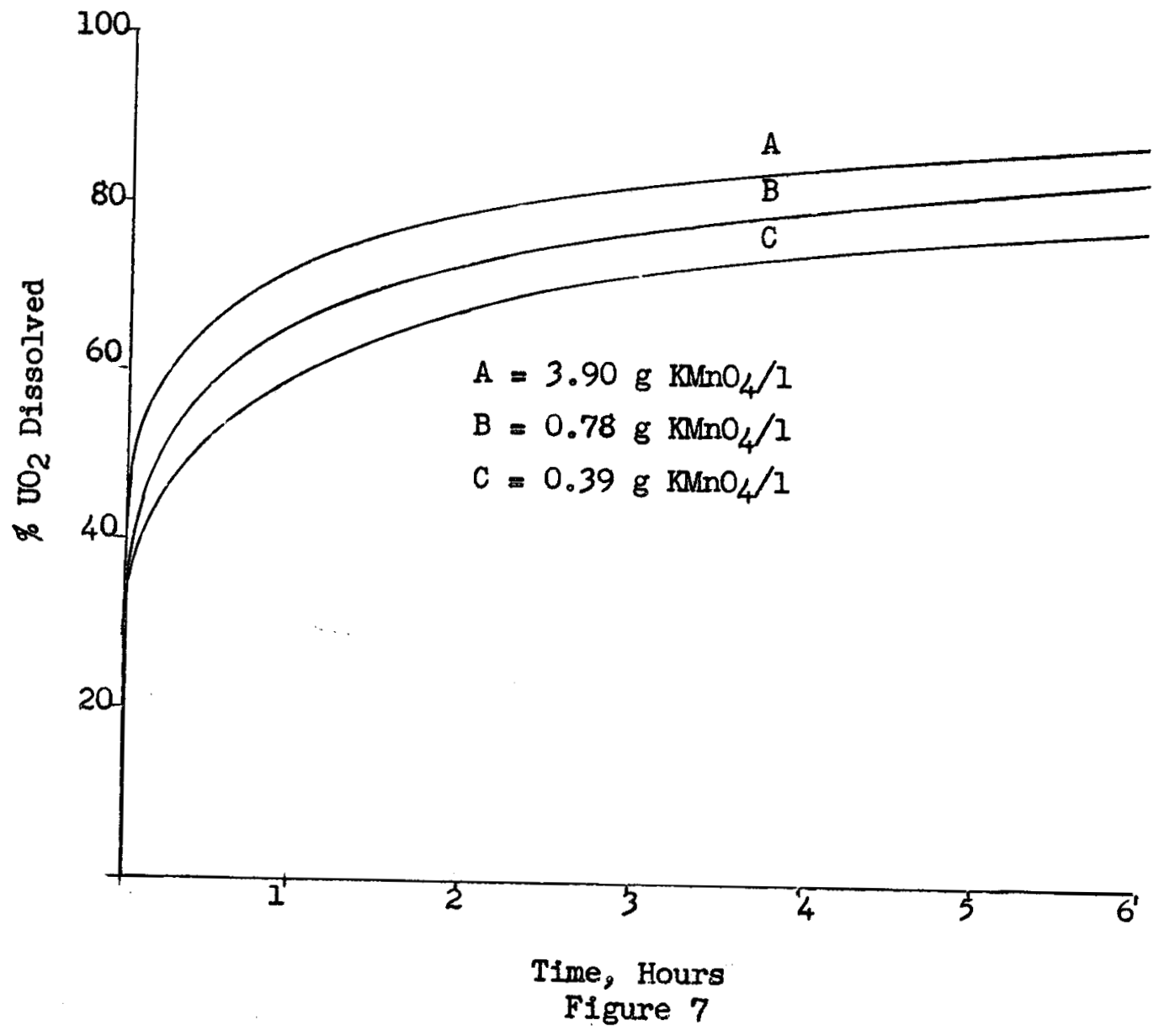

Dissolution of $\mathrm{VO}_{2}$ in Carbonate-Bicarbonate Solution Using $\mathrm{KMnO}_{4}$ as oxidant 


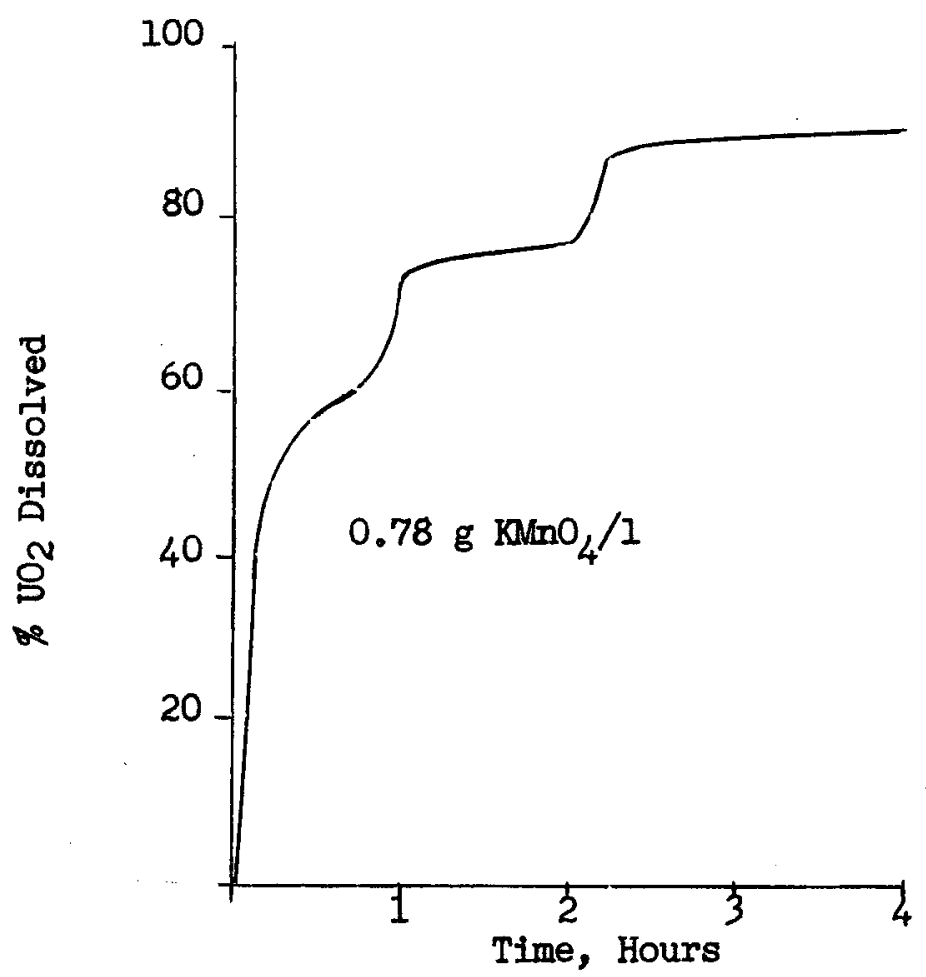

Figure 8. Dissolution of $\mathrm{UO}_{2}$ in Carbonate-Bicarbonate Solution Using $\mathrm{KMnO}_{4}$ as Oxidant with a Surface Regeneration After 30 and 120 Minutes

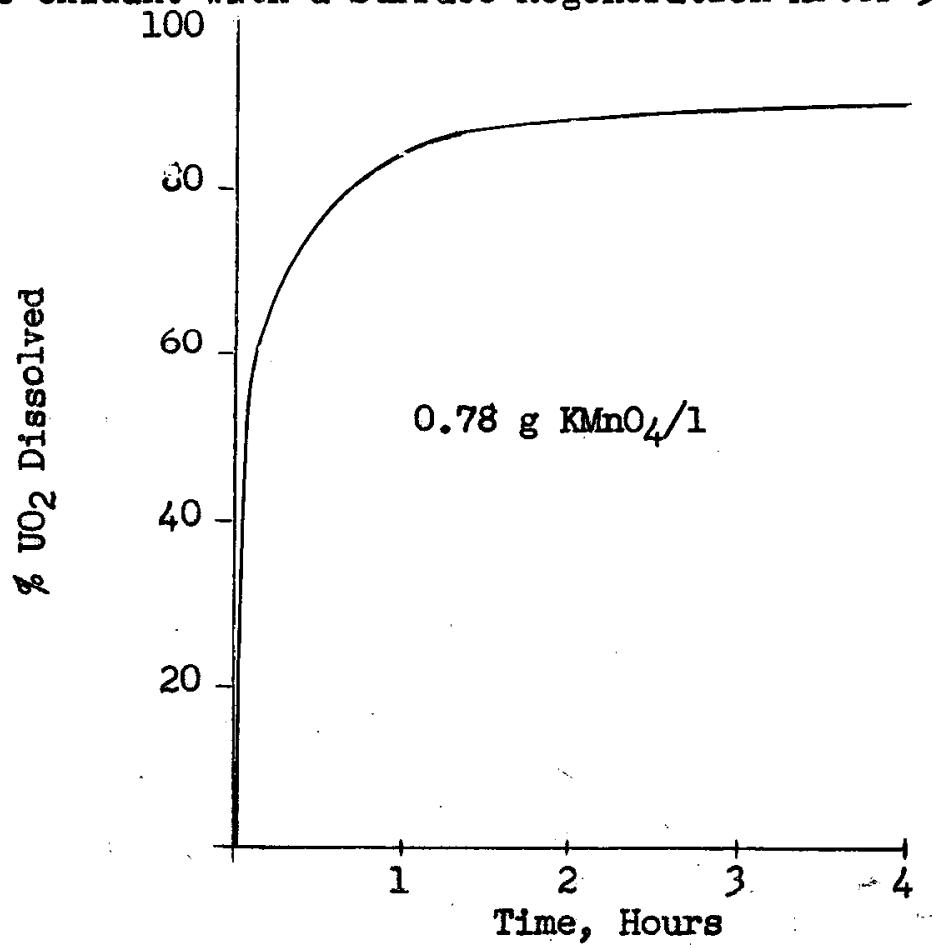

Figure 9. Dissolution of $\mathrm{UO}_{2}$ in Carbonate-Bicarbonate Solution Using $\mathrm{KMnO}_{4}$ as Oxidant and Beach Sand for the Purpose of Attrition 


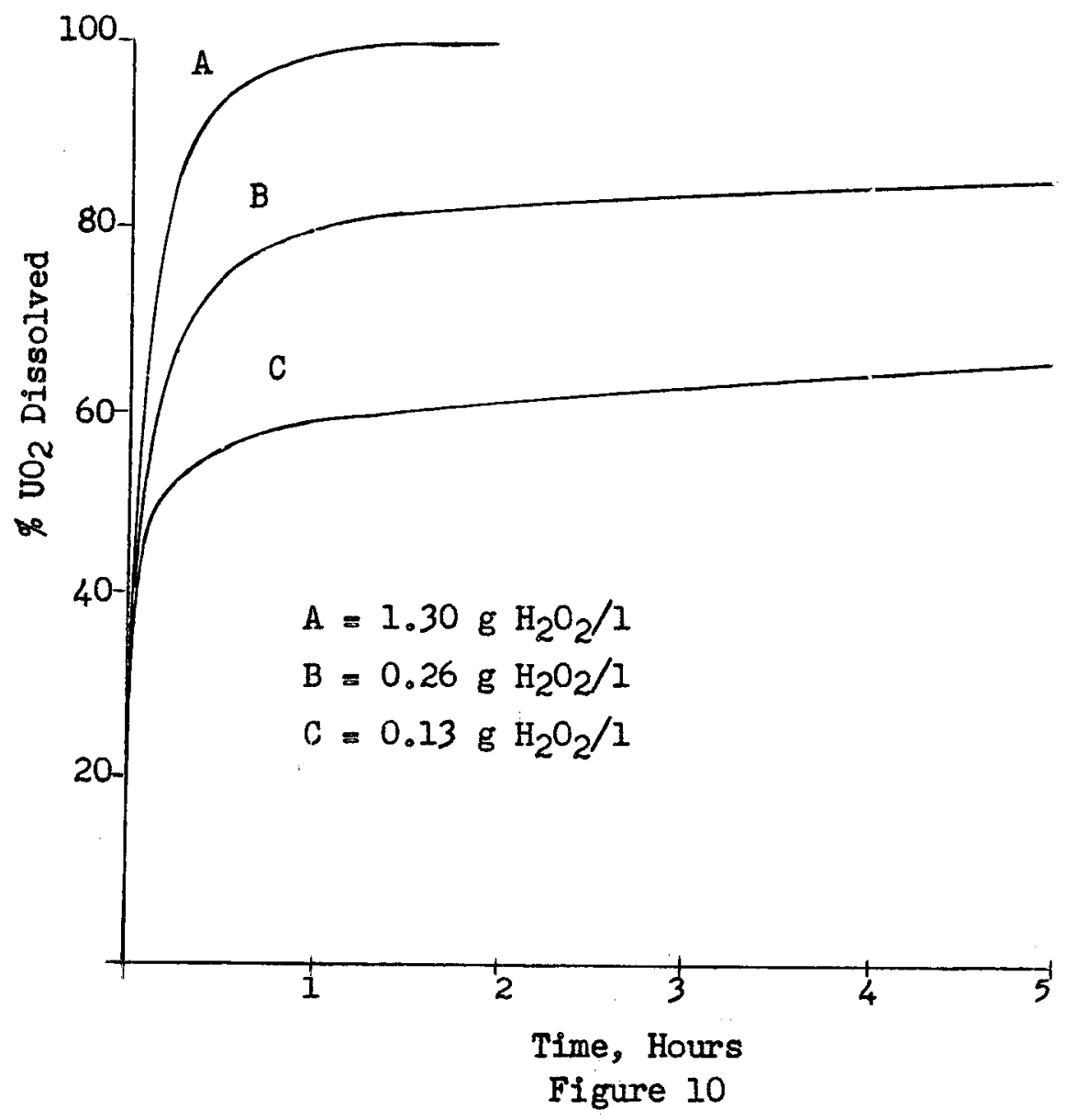

Dissolution of $\mathrm{UO}_{2}$ in Carbonate-Bicarbonate Solution Using $\mathrm{H}_{2} \mathrm{O}_{2}$ as Oxidant 
WIN -86

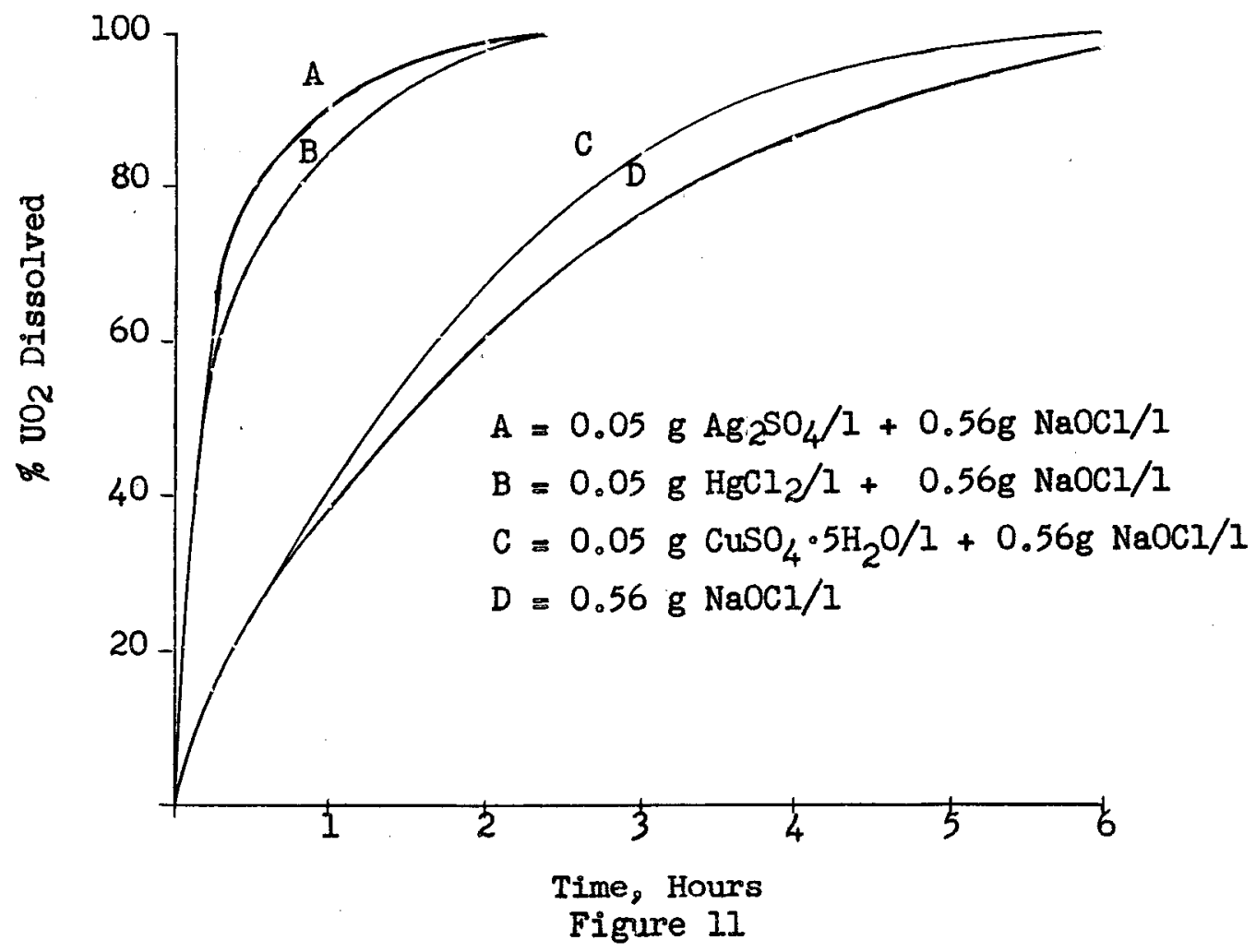

Dissolution of $\mathrm{vO}_{2}$ in Carbonate-BIcarbonate Solution by Catalysis of Sodium Hypochlorite Oxidation 
WIN-86

$-41$.

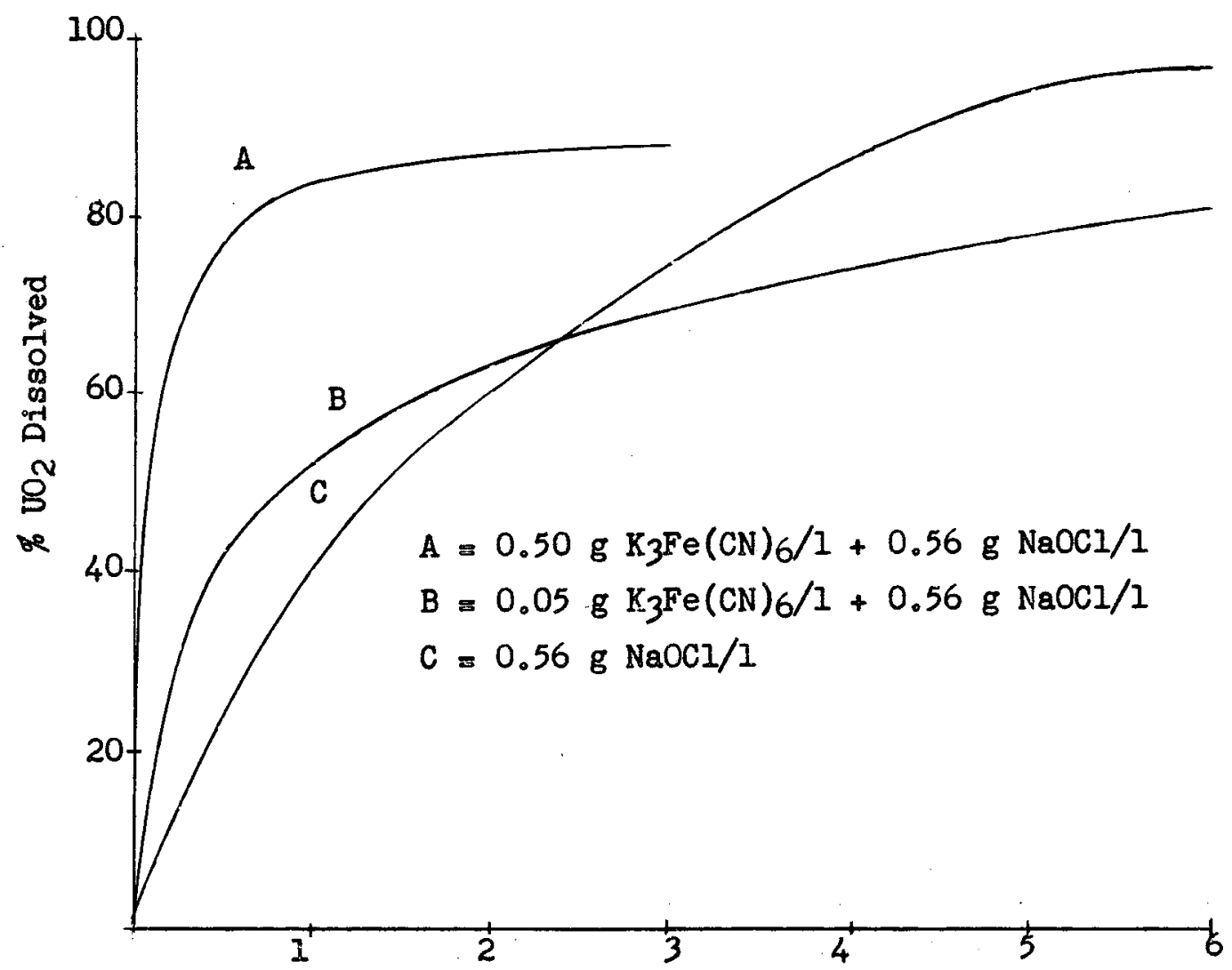

Time, Hours

Figure 12

Dissolution of $\mathrm{UO}_{2}$ in Carbonate-Bicarbonate Solution Using $\mathrm{K}_{3} \mathrm{Fe}(\mathrm{CN})_{6}$ to Catalyze the $\mathrm{NaOCl}$ Oxidation 


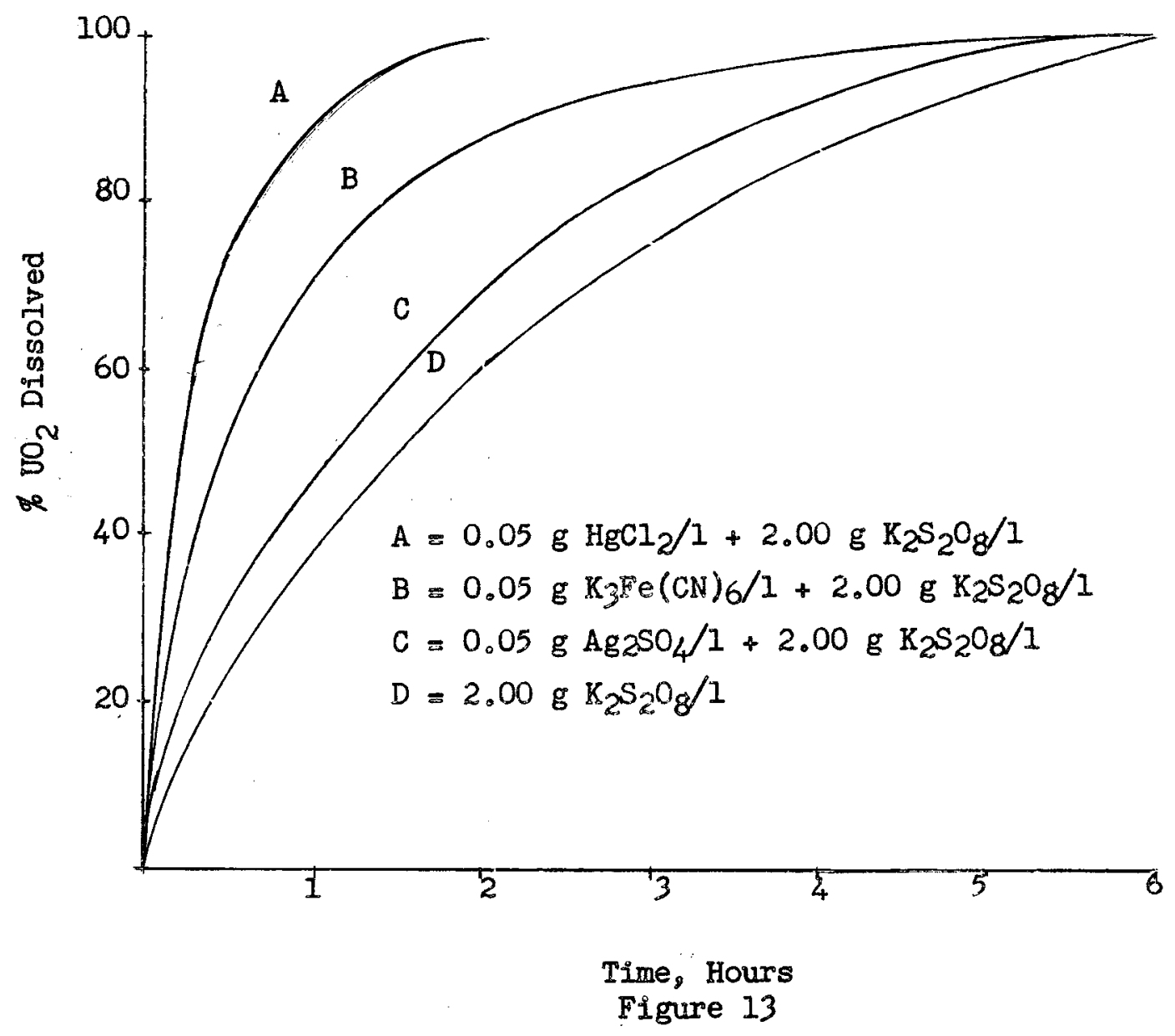

Dissolution of $\mathrm{UO}_{2}$ in Carbonate-Bicarbonate Solution by Catalysis of $\mathrm{K}_{2} \mathrm{~S}_{2} \mathrm{O}_{8}$ Oxidation 
WIN -86

-43 -

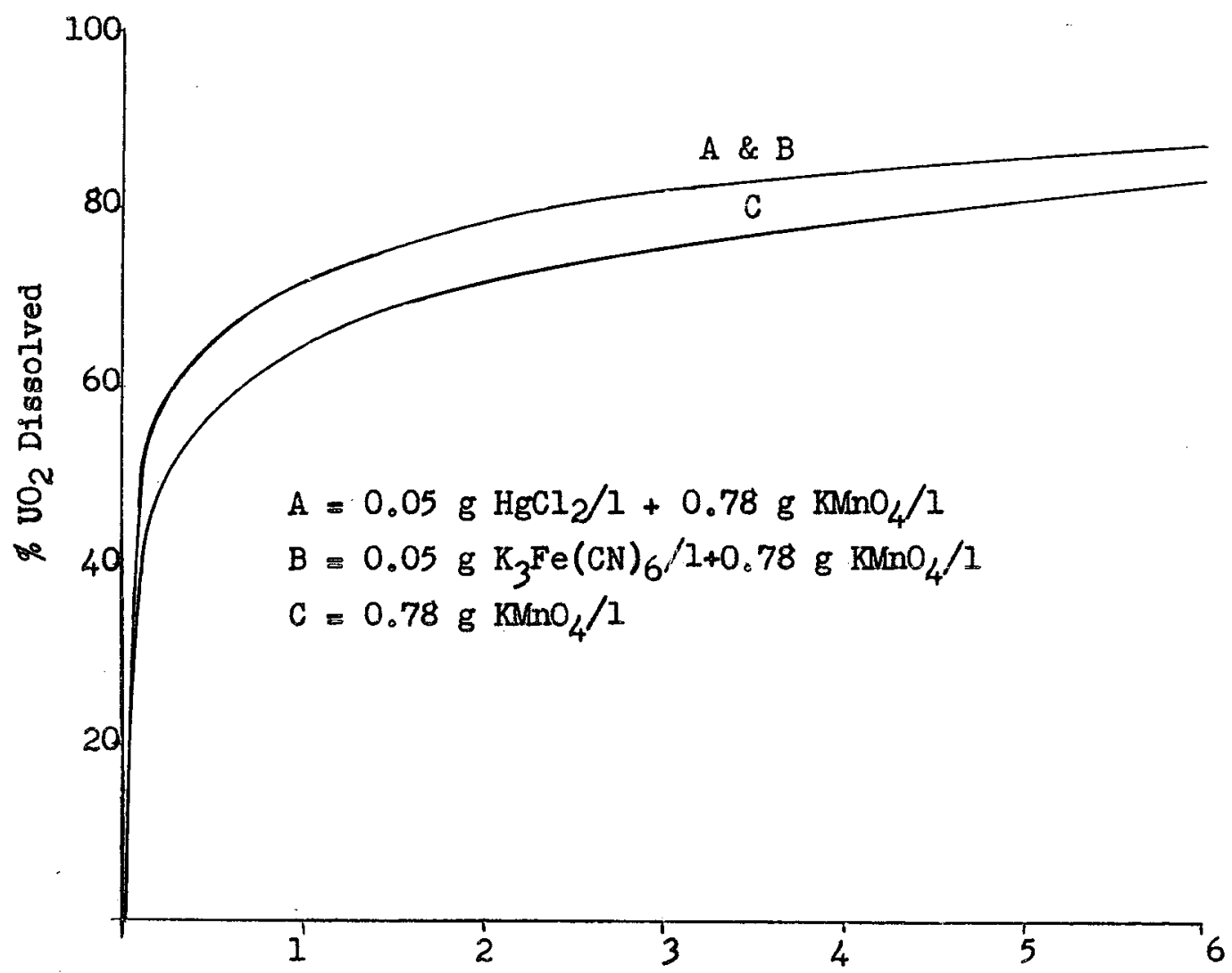

Time, Hours

Figure 14

Dissolution of $\mathrm{VO}_{2}$ in Carbonate-Bicarbonate Solution by Catalysis of $\mathrm{KMnO}_{4}$ Oxidation 


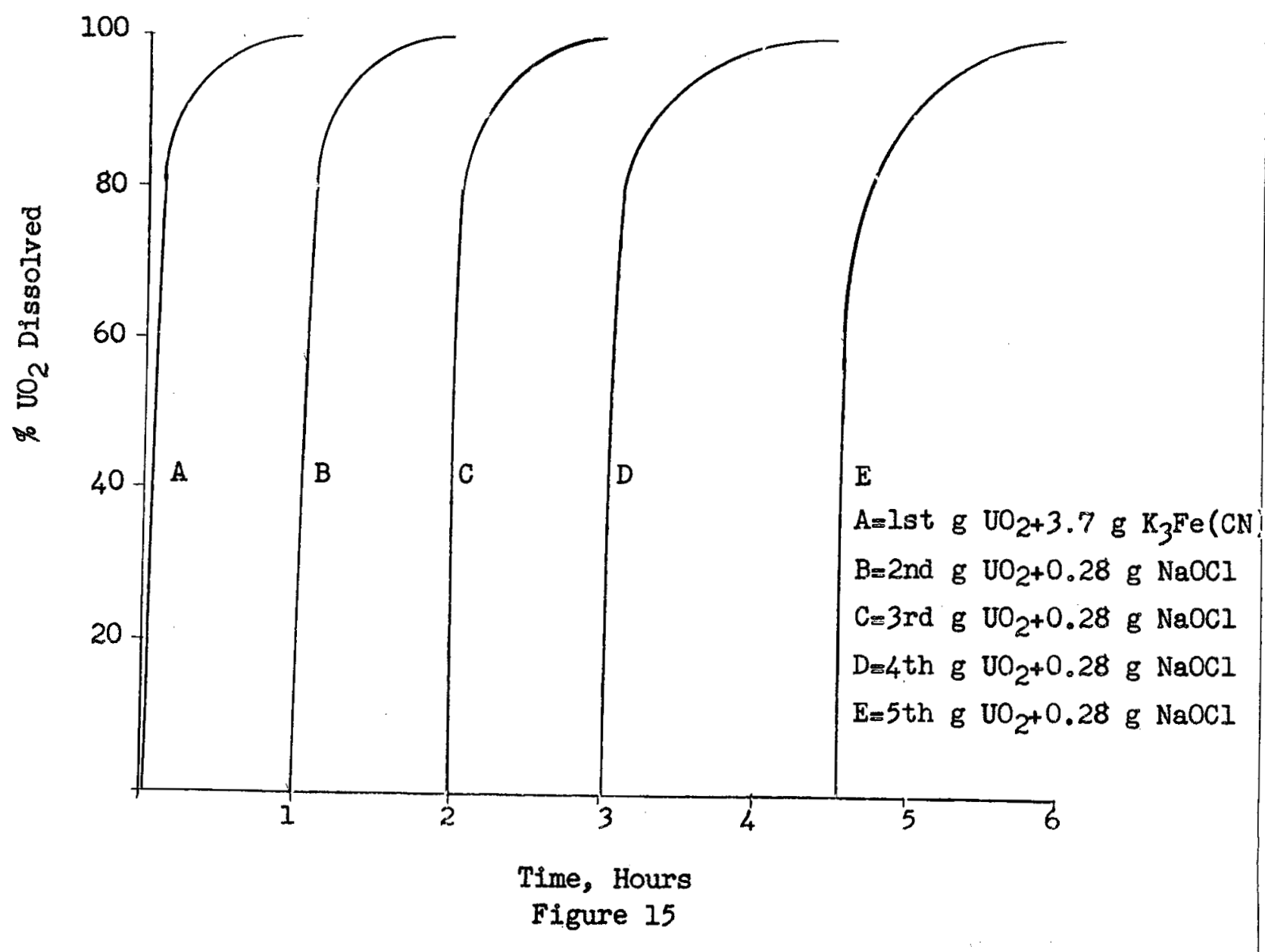

Dissolution of Successive Charges of $\mathrm{UO}_{2}$ in Carbonate-Bicarbonate Solution Using $\mathrm{K}_{3} \mathrm{Fe}(\mathrm{CN})_{6}$ which is Reoxidized by $\mathrm{NaOCl}$ 